\title{
34. DEVELOPMENT OF PHYSICAL PROPERTIES RELATIONSHIPS, INTERHOLE COMPOSITE DEPTH PROFILES, AND SEDIMENTOLOGIC GROUND TRUTHING OF MULTI-SENSOR CORE MEASUREMENTS: A SYNTHESIS OF RESULTS ${ }^{1}$
}

\author{
Frank R. Rack, ${ }^{2}$ Jan Bloemendal, ${ }^{3}$ Thomas C.W. Wolf-Welling, ${ }^{4}$ Suzanne O'Connell, ${ }^{5}$ Michel Cremer, ${ }^{6}$ Amelie Winkler, ${ }^{4}$ Jörn \\ Thiede, ${ }^{4}$ Kevin Black, ${ }^{7}$ and Julie Hood $^{8}$
}

\begin{abstract}
This paper presents an overview of the physical properties and sedimentologic results from six Ocean Drilling Program Leg 151 sites cored on the Iceland Plateau (Hole 907A), in the Fram Strait region (Sites 908 and 909), and on the Yermak Plateau (Sites 910-912). The primary objective of this paper is to determine to what extent wet bulk density measured using the gamma-ray attenuation porosity evaluator (GRAPE) can be used to interpret textural and compositional changes in sediment accumulation at the various sites around the Nordic Seas and Arctic Ocean. To accomplish this objective, we have first established quantitative relationships between discrete measurements of bulk density and GRAPE bulk density at nine holes and have evaluated the frequency distribution of GRAPE bulk density data at the same holes to detect significant differences between sites. We have also evaluated the frequency distribution of magnetic susceptibility data at these holes because this rock magnetic parameter is most often used in combination with GRAPE measurements for correlation purposes. These two parameters are also used for evaluating compositional and textural changes in sedimentary inputs.

Composite depth profiles have been developed for three sites (Sites 908,909, and 911) using both GRAPE bulk density and magnetic susceptibility measurements made on cores from multiple, adjacent holes at these sites. The composite depth profiles provide a more continuous record of property variations in the upper 100 meters below seafloor at a given site than is provided by the data collected at a single hole. The composites also provide the framework for more detailed paleoceanographic and paleoclimatic analyses of the records from these sites (i.e., spectral analysis of time series, astronomic tuning of records, etc.). These activities will be pursued in future contributions related to these data.

Efforts have been made to identify the sources of variation in the GRAPE bulk density records, and to a lesser extent the magnetic susceptibility records, using the available "ground truth" provided by sedimentologic analyses of discrete samples from selected holes. Textural and mineralogic analyses are compared to GRAPE bulk density records to identify to what extent we are able to explain the density fluctuations in terms of (1) changes in the accumulation of coarse-grained material in various grain-size subfractions, which are primarily transported to the deep sea by sea ice and icebergs during glacial intervals and are influenced by oceanic currents to varying extents, and (2) by changes in the mineralogy and in the relative percentages of various sedimentary inputs, which may provide information about changing source regions for these materials between glacial and interglacial periods in the Nordic Seas and Arctic Ocean.
\end{abstract}

\section{INTRODUCTION}

\section{Physical Properties of Sediments Derived from Multi-Sensor Data}

Gamma-ray attenuation porosity evaluator (GRAPE) bulk density, magnetic susceptibility, and compressional velocity measurements on sediment cores have been used in both geotechnical studies and in paleoceanographic investigations. The goals of some of these investigations have focused on using changes in sediment physical

Thiede, J., Myhre, A.M., Firth, J.V., Johnson, G.L., and Ruddiman, W.F. (Eds.), 1996. Proc, ODP, Sci. Results, 151: College Station, TX (Ocean Drilling Program).

${ }^{2}$ Ocean Mapping Group, Department of Geodesy and Geomatics Engineering, P.O. Box 4400, University of New Brunswick, Fredericton, New Brunswick E3B 5A3, Canada.rack@omg.unb.ca

'Department of Geography, University of Liverpool, Roxby Building, Liverpool L69 3BX, United Kingdom.

${ }^{4}$ GEOMAR Research Center for Marine Geosciences, Wischhofstraße 1-3, Building 4, D-24148 Kiel, Federal Republic of Germany.

sDepartment of Earth and Environmental Sciences, Wesleyan University, Middletown, CT 06459 , U.S.A.

${ }^{6}$ Departement de Geologie et Oceanographie, URA CNRS 197, Universite de Bordeaux I, Avenue des Facultes, 33405 Talence Cedex, France.

'Department of Geology, University of St. Andrews, St. Andrews, Scotland, United Kingdom.

${ }^{8}$ Applied Marine Physics, Rosenstiel School of Atmospheric and Marine Science, University of Miami, Miami, FL 33149, U.S.A. properties to reconstruct the history of lithologic variations modulated by climatic changes (Bloemendal and deMenocal, 1989; Bloemendal et al., 1988, 1993; Mayer, 1991; Mayer et al., 1993; Mienert and Bloemendal, 1989; Mienert et al., 1988; Rack and Pittenger, 1992; Robinson, 1986; Robinson and McCave, 1994; Robinson and Maslin, 1995), to interpret seismic lithostratigraphy through changes in acoustic impedance measured in cores (Mayer, 1979a, b; Mayer et al., 1985; Hempel et al., 1989), to identify the latitudinal migration of zonal oceanographic fronts (Rack and Palmer-Julson, 1992; Rack, 1993), to investigate atmospheric transport of dust from continental source regions to the oceans (deMenocal et al., 1991; Doh et al., 1988; Rack et al., 1995), and to improve the stratigraphic resolution of marine sediment records through astronomic tuning of GRAPE and/or magnetic susceptibility measurements for use in paleoceanographic studies (Pisias et al., 1995; Shackleton et al., 1992, 1995; Mienert and Chi, 1995).

The GRAPE provides near-continuous, nondestructive measurements of bulk density on whole-round cores. These data are very useful in many sedimentary environments and their potential has expanded considerably in the past five to ten years. In regions of the equatorial Pacific, where the preserved skeletons of microscopic marine plants and animals comprise the bulk of pelagic sediments, both mineralogically related differences in the packing of sedimentary grains and differences in grain density (i.e., biogenic carbonate $=$ $2.72 \mathrm{~g} / \mathrm{cm}^{3}$; biogenic silica $=2.1-2.3 \mathrm{~g} / \mathrm{cm}^{3}$ ) appear to control wet bulk density variations (Mayer, 1979a, 1991; Herbert and Mayer, 
1991); however, the importance of packing may be emphasized in sedimentary environments with significant amounts of clay minerals and quartz (Herbert and Mayer, 1991).

\section{Sedimentary History of the Fram Strait and Svalbard Region}

Two of the primary objectives of Leg 151 were to document the history of ice-rafted sedimentation in the Nordic Seas (Fig. 1), and to study the influence of Fram Strait as a gateway between the Arctic Ocean and the Nordic Seas. Fram Strait acts as a depositional estuary for much of the ice-rafted and current-transported material carried by Arctic sea ice from the East Siberian Sea to the Greenland Sea (Honjo, 1990; Bischof et al., 1990). Ice-rafted debris travels across the eastern Arctic Ocean primarily via the Transpolar Drift, which merges with the southward-flowing East Greenland Current upon exiting Fram Strait (Carmack, 1990). The northward-flowing Atlantic water, which enters Fram Strait as the West Spitsbergen Current, is generally low in suspended sedimentary material, although some sediment from glacial output is transported northward along the west coast of Spitsbergen (Kristoffersen, 1990). Uplift and erosion of sediment from Svalbard and the Barents Shelf following glacier retreat have provided an abundant source of Pliocene-Pleistocene sediment into the eastern part of the strait and further to the south, where extensive wedges of sediment have been deposited on the continental slope and at the mouth of east-west-trending troughs (Myhre and Eldholm, 1988; Vorren et al., 1991; Riis and Fjeldskaar, 1992; Eidvin et al., 1993; Faleide et al., in press).

Late Cenozoic sedimentation off the western Svalbard Margin at about $78^{\circ} \mathrm{N}$ consists of two primary sequences separated by a regional unconformity, which is estimated to have formed at about 1.0 to $0.8 \mathrm{~m} . \mathrm{y}$. ago (Andersen et al., 1994). This unconformity is probably associated with an amplification of glaciations in the Nordic Seas (Jansen and Sjøholm, 1991). Another prominent seismic reflector along the western Svalbard Margin is dated at 0.73 to $0.44 \mathrm{Ma}$ (Andersen et al., 1994; Faleide et al., in press; Hjelstuen et al., in press) on the basis of correlations to sequences in shallow boreholes further to the south (Sættem et al., 1992).

\section{Physical Oceanography}

The Nordic Seas are the principle conduit for surface- and deepwater communication between the North Atlantic and the Arctic Ocean (Fig. 1). The regional sea-ice cover in the Nordic Seas varies both seasonally and interannually, but generally there is heavy sea ice along the Greenland Margin and decreasing sea-ice coverage towards the region influenced by northward-flowing, warm Atlantic waters in the Norwegian Current. The Fram Strait region provides the only deep connection between the Arctic Ocean and the Nordic Seas (width $=450 \mathrm{~km}$, sill depth $=2600 \mathrm{~m}$ ), and in this region warm, saline Atlantic waters are exchanged for cold, fresh Arctic waters (Aagaard et al., 1985; Hunkins, 1990; Kristoffersen, 1990).

The physical oceanography of the Fram Strait region is highly complex and dynamic (Fig. 2). Northward flow in the West Spitsbergen Current, on the eastern side of the strait, separates into several current branches under the sea ice north of Svalbard (Manley et al., 1992; Muench et al., 1992; and references therein). A portion of the northward flow also curves westward and mixes with the southwardflowing East Greenland Current, and the East Greenland Gyre. According to Aagaard et al. (1988), average northward flow velocities in the upper $950 \mathrm{~m}$ of Fram Strait are $8-15 \mathrm{~cm} / \mathrm{s}$, with peak values reaching $40 \mathrm{~cm} / \mathrm{s}$, which is sufficiently strong to erode seafloor sediments. The southward-flowing East Greenland Current, which reaches velocities of $20-30 \mathrm{~cm} / \mathrm{s}$ and follows the Greenland shelf after crossing the northern part of the Fram Strait (Vinje and Finneskaasa, 1986), provides the major transport path for ice outflowing from the Arctic Ocean.

\section{Objectives of This Study}

The primary objective of this paper is to determine to what extent wet bulk density measured using the GRAPE can be used to interpret textural and compositional changes in sediment accumulation at the various sites around the Nordic Seas and Arctic Ocean. To accomplish this objective, we first established quantitative relationships between discrete measurements of bulk density and whole-core measurements of GRAPE bulk density at six sites (Table 1). We then evaluated the frequency distribution of GRAPE bulk density and magnetic susceptibility data to detect any significant statistical differences in the distribution of data between sites. Efforts have been made to identify the sources of variation in the GRAPE bulk density records, and to a lesser extent the magnetic susceptibility records, using the available "ground truth" provided by sedimentologic analyses of discrete samples from selected holes. Textural and mineralogic analyses are compared to GRAPE bulk density records to identify to what extent we are able to explain the density fluctuations in terms of (1) changes in the accumulation of coarse-grained material in various grain-size subfractions, which are primarily transported to the deep sea by sea ice and icebergs during glacial intervals and are influenced by oceanic currents to varying extents, and (2) by changes in the mineralogy and in the relative percentages of various sedimentary inputs, which may provide information about changing source regions for these materials between glacial and interglacial periods in the Nordic Seas and Arctic Ocean.

\section{METHODS}

\section{Physical Properties, Nondestructive Measurements, and Composite Depth Profiles}

GRAPE wet bulk density measurements are routinely made on Deep Sea Drilling Project (DSDP) and Ocean Drilling Program (ODP) cores. The GRAPE sensor is mounted on a multi-sensor track (MST), which provides nondestructive, whole-core measurements on a semicontinuous basis. The downcore resolution of these measurements is determined by a combination of operational considerations and sensor-specific technical characteristics, but is typically $0.5-2.0$ $\mathrm{cm}$ between GRAPE measurements. The MST aboard the JOIDES Resolution includes additional sensors for measuring magnetic susceptibility, compressional wave velocity, and natural gamma emissions of cores. Measurements of magnetic susceptibility were made using the Bartington Instruments MS-2 susceptibility sensor, which was equipped with an 80 -mm-diameter loop; measurements were typically made every 3 to $5 \mathrm{~cm}$. Additional information about the operation of MST and its sensor characteristics is provided in Myhre, Thiede, Firth, et al. (1995), along with details about the methods for obtaining discrete measurements of index properties (i.e., bulk density, porosity, and water content) during Leg 151.

We have decided to focus this synthesis exclusively on cores obtained using the advanced hydraulic piston corer (APC), except at Site 910, where only limited APC core recovery was available because of the presence of stiff sediment at shallow burial depths. The raw MST data collected aboard the JOIDES Resolution were edited to remove data from disturbed sedimentary intervals, as identified during from an examination of core photographs. Discrete sample data were also edited for quality before being used to develop the interrelationships presented in this paper. The quality of discrete data was determined by reviewing the shipboard mass and volume measurements for individual samples and by evaluating the consistency of the various index properties calculated from these measurements. Samples having calculated grain densities that were outside of the range typically encountered in marine and glacial-marine sediments (i.e., 2.0 to $3.0 \mathrm{~g} / \mathrm{cm}^{3}$ ) were omitted from the data set. The methods used in the development of composite depth profiles of multi-sensor 


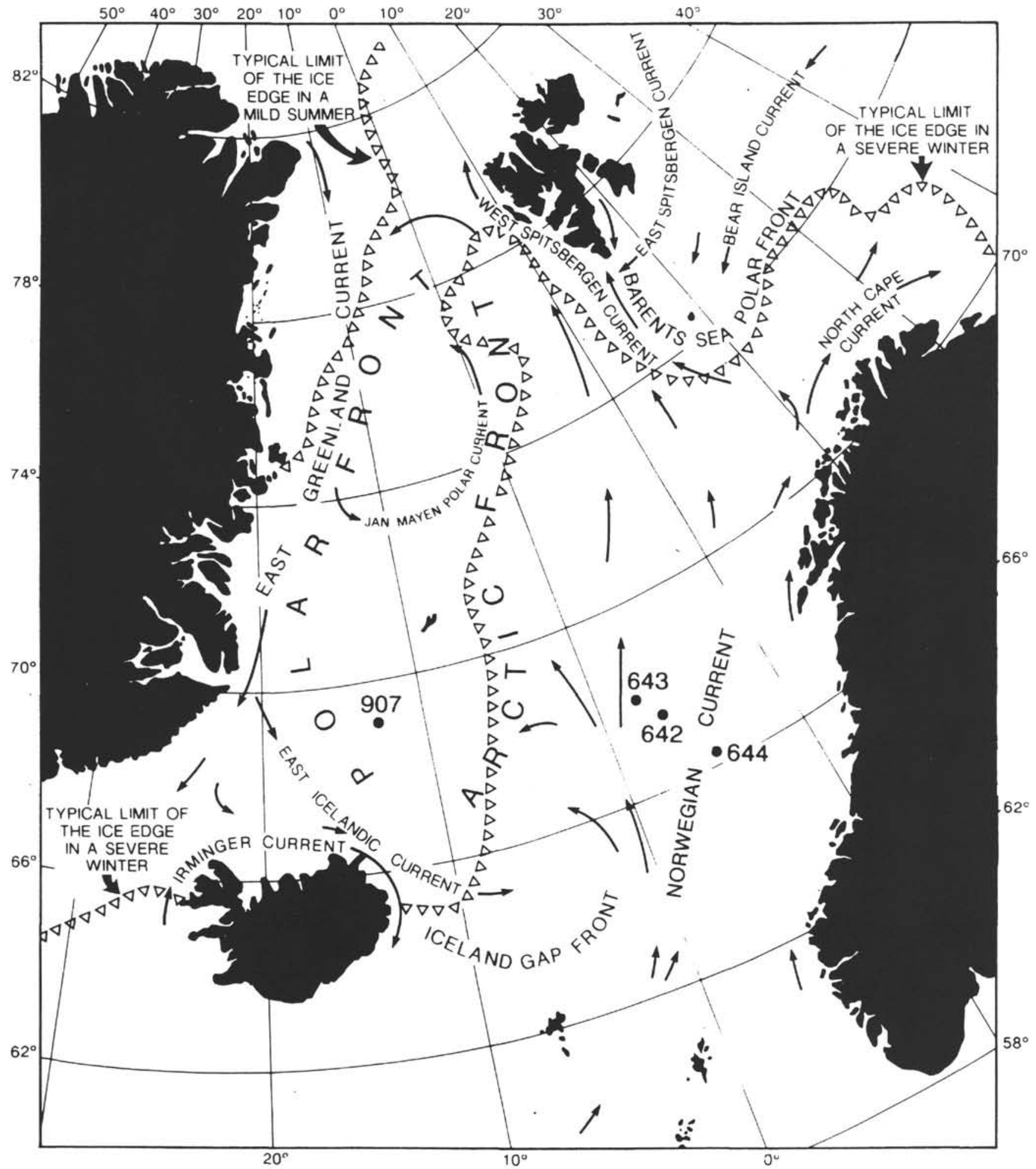

Figure 1. Map of the Norwegian-Greenland Sea and surrounding regions, showing the approximate positions of oceanographic fronts and seasonal sea-ice limits. The locations of Site 907 on the Iceland Plateau and Sites 642-644 on the Vøring Plateau (Leg 104) are also shown (from Fronval and Jansen, this volume). 
Figure 2. Upper-layer circulation patterns of the various currents in the northern Greenland Sea, Yermak Plateau, and surrounding areas (Manley et al., 1992; from Myhre, Thiede, Firth, et al., 1995).

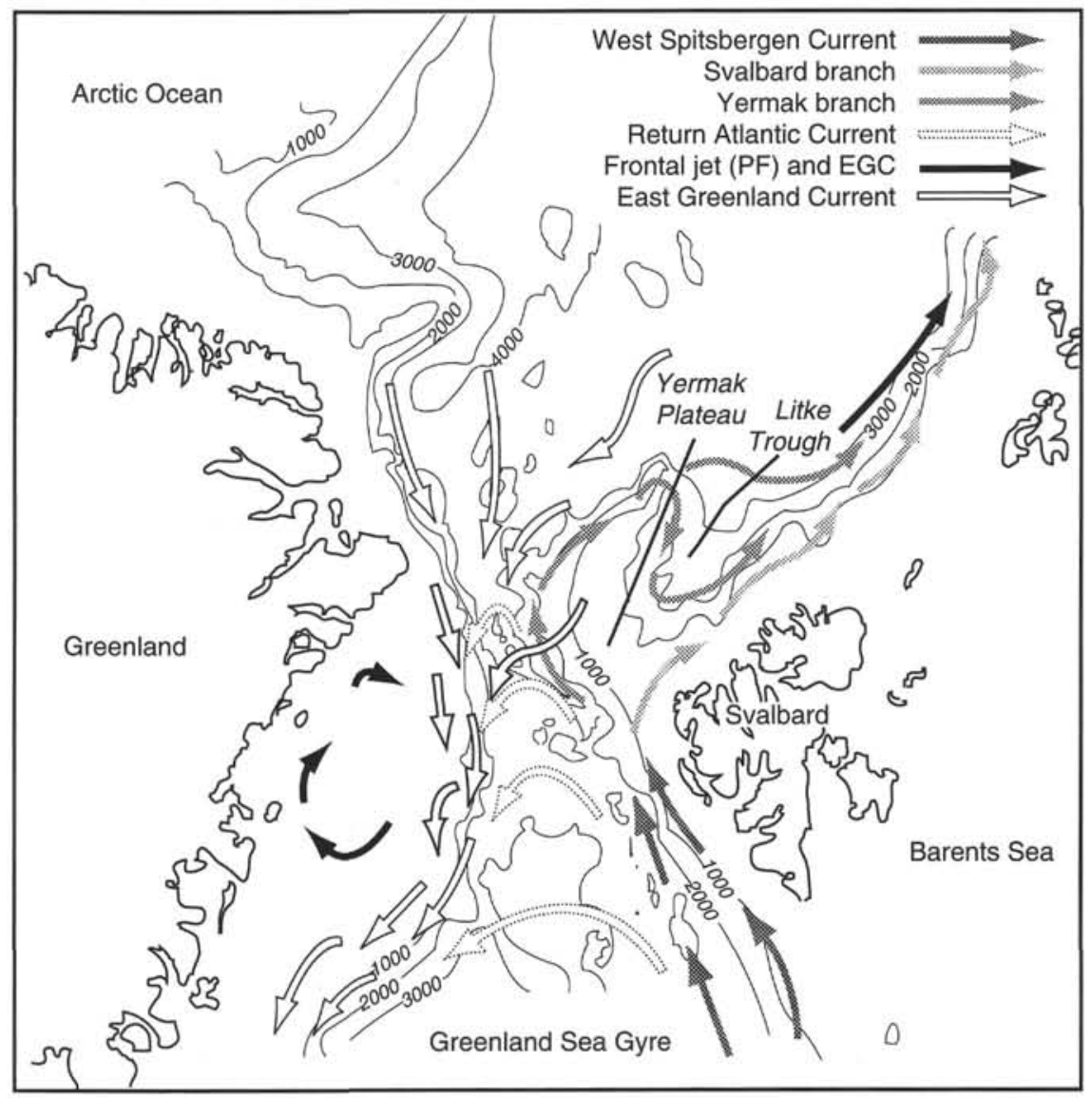

Table 1. Locations of selected Leg 151 sites.

\begin{tabular}{cccc}
\hline Hole & Latitude & Longitude & $\begin{array}{c}\text { Water depth } \\
(\mathrm{mbsl})\end{array}$ \\
\hline $907 \mathrm{~A}$ & $69^{\circ} 14.989^{\prime} \mathrm{N}$ & $12^{\circ} 41.894^{\prime} \mathrm{W}$ & 1800.83 \\
$908 \mathrm{~A}$ & $78^{\circ} 23.112^{\prime} \mathrm{N}$ & $01^{\circ} 21.637^{\prime} \mathrm{E}$ & 1273.52 \\
$908 \mathrm{~B}$ & $78^{\circ} 23.125^{\prime} \mathrm{N}$ & $01^{\circ} 21.644^{\prime} \mathrm{E}$ & 1273.02 \\
$909 \mathrm{~A}$ & $78^{\circ} 35.065^{\prime} \mathrm{N}$ & $03^{\circ} 04.378^{\prime} \mathrm{E}$ & 2519.04 \\
$909 \mathrm{~B}$ & $78^{\circ} 35.074^{\prime} \mathrm{N}$ & $03^{\circ} 04.380^{\prime} \mathrm{E}$ & 2519.12 \\
$910 \mathrm{~A}$ & $80^{\circ} 15.882^{\prime} \mathrm{N}$ & $06^{\circ} 35.405^{\prime} \mathrm{E}$ & 556.38 \\
$910 \mathrm{~B}$ & $80^{\circ} 15.876^{\prime} \mathrm{N}$ & $06^{\circ} 35.451^{\prime} \mathrm{E}$ & 556.98 \\
$910 \mathrm{C}$ & $80^{\circ} 15.896^{\prime} \mathrm{N}$ & $06^{\circ} 35.430^{\prime} \mathrm{E}$ & 556.38 \\
$910 \mathrm{D}$ & $80^{\circ} 15.881^{\prime} \mathrm{N}$ & $06^{\circ} 35.424^{\prime} \mathrm{E}$ & 556.54 \\
$911 \mathrm{~A}$ & $80^{\circ} 28.466^{\prime} \mathrm{N}$ & $08^{\circ} 13.640^{\prime} \mathrm{E}$ & 901.58 \\
$911 \mathrm{~B}$ & $80^{\circ} 28.476^{\prime} \mathrm{N}$ & $08^{\circ} 13.636^{\prime} \mathrm{E}$ & 900.98 \\
$912 \mathrm{~A}$ & $79^{\circ} 57.557^{\prime} \mathrm{N}$ & $05^{\circ} 27.360^{\prime} \mathrm{E}$ & 1036.76 \\
$912 \mathrm{~B}$ & $79^{\circ} 57.533^{\prime} \mathrm{N}$ & $05^{\circ} 27.397^{\prime} \mathrm{E}$ & 1037.45 \\
\hline
\end{tabular}

data, and the integration of data from individual holes from each site, will be discussed together with the results in the next section.

\section{Ground Truth Investigations}

Preliminary results from grain-size analyses of bulk sediment samples in Hole 907A, from 38 to 62 meters below sea floor (mbsf), are presented to aid in the interpretation of GRAPE bulk density and magnetic susceptibility data from this hole. These grain-size data were collected using a Coulter Counter located at the University of Liverpool (United Kingdom). Only the mean grain-size and standard deviation envelope for individual samples are presented herein; sub- sequent data and results from these samples will be included in future contributions (K. Black, pers. comm., 1995).

Data from coarse-fraction sediment ( $>63 \mu \mathrm{m})$ studies from Holes 908A and 909A are used to provide "ground truth" for interpreting changes in GRAPE bulk density measurements from these holes. The procedures used to generate the coarse-fraction data are found in Wolf-Welling et al. (this volume), where the wt\% for individual grain-size subfractions are presented (i.e., 63- to $125-\mu \mathrm{m}, 125-$ to $250-\mu \mathrm{m}, 250-$ to $500-\mu \mathrm{m}, 500$ to $1000-\mu \mathrm{m}$, and $>1000-\mu \mathrm{m}$ grain-size subfractions), as well as sediment compositional information obtained from grain counts of the 125 - to $500-\mu \mathrm{m}$ grain-size subfraction (data given as grain percentages). Herein, we have recalculated the data presented in Wolf-Welling et al. (this volume), to plot individual grain-size subfractions of the $>63-\mu \mathrm{m}$ size-fraction as wt $\%$ of the total sample weight, rather than as $w t \%$ of the $>63-\mu \mathrm{m}$ size-fraction. We have also regrouped some of the wt $\%$ data presented by WolfWelling et al. (this volume) to plot the $125-$ to $500-\mu \mathrm{m}$, and $>500-\mu \mathrm{m}$ grain-size subfractions in two plots, rather than as four separate groupings.

The merging of the 125 - to $250-\mu \mathrm{m}$ and 250 - to $500-\mu \mathrm{m}$ grain-size subfractions was recommended by Wolf-Welling et al. (this volume) and by previous studies (Henrich et al., 1989; Wolf and Thiede, 1991) because (1) both subfractions seem to be most representative of the $>63-\mu \mathrm{m}$ fraction, and (2) the use of the $>125-\mu \mathrm{m}$ grain-size subfraction avoided problems associated with current-influenced deposits (Wolf-Welling et al., this volume; Cremer et al., this volume).

Finally, we will discuss the results from an analysis of X-ray images of whole-round cores from Hole 910D (Rack et al., this volume), which provide the preliminary ground truthing of multi-sensor data 

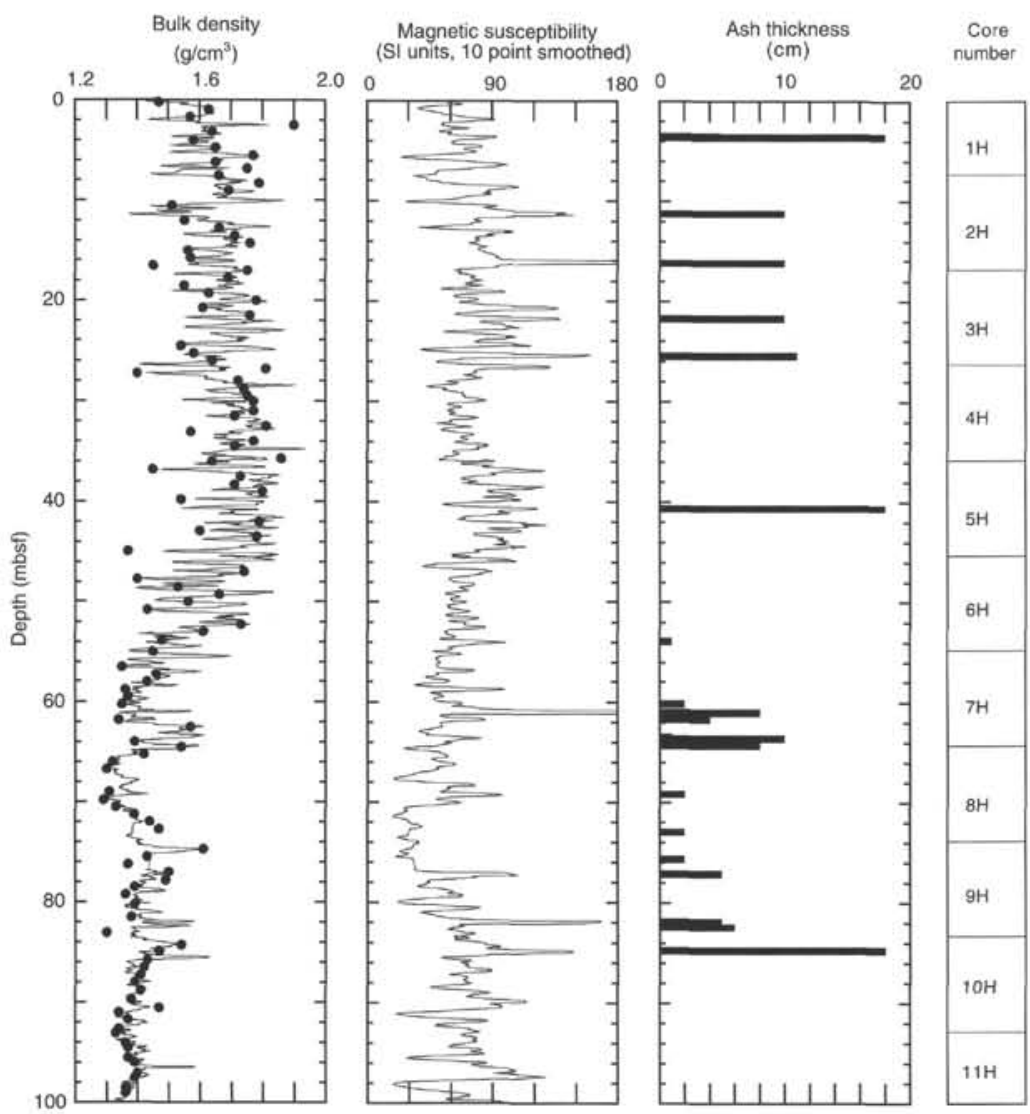

Figure 3. Summary of GRAPE bulk density and magnetic susceptibility data (0-100 mbsf), Hole $907 \mathrm{~A}$. The downhole position and thickness of individual ash layers and the location of core breaks are shown.

from that hole, and compare them with data from Holes 910A and 910C.

\section{RESULTS AND DISCUSSION}

\section{Multi-Sensor Measurements vs. Discrete Measurements of Physical Properties}

\section{Iceland Plateau: Hole 907A}

A 216-m-long sediment sequence was recovered on the Iceland Plateau from Hole 907A (Table 1; Fig. 1), located about $250 \mathrm{~km}$ southwest of Jan Mayen and $350 \mathrm{~km}$ northeast of Iceland. The upper Miocene through Pleistocene sediments recovered from this hole are divided into three lithologic units based mainly on their varying amounts of biogenic and siliciclastic material and volcanic glass. The boundaries of these lithologic units generally correspond to geotechnical unit boundaries (Myhre, Thiede, Firth, et al., 1995).

The sediments in the upper portion of Hole 907A are unlithified and generally consist of dark grayish brown silty clay and clayey silt, with scattered dropstones $(>0.5 \mathrm{~cm})$. Lithologic Unit I ( $0-16.8 \mathrm{mbsf})$ is distinguished by the presence of abundant foraminifers. Lithologic Unit II (16.8-56.3 mbsf) is characterized by the absence of biogenic carbonate and silica, and by an enrichment in silt- and sand-sized siliciclastic grains. Lithologic Unit III (56.3-118.1 mbsf) is defined by the presence of biogenic silica, a downcore increase in volcanic glass content, and a decrease in quartz and feldspar abundance (Myhre, Thiede, Firth, et al., 1995). These compositional changes are observed as a pronounced uphole increase in mean GRAPE bulk density values, as biogenic silica-rich sediments are replaced by more siliciclastic grains (Fig. 3). This change is due to the increased abundance of biogenic silica-rich sediments containing diatom and radiolarian skeletons, which are characterized by low grain densities and high porosities.

Most ash layers in the upper $100 \mathrm{mbsf}$ of Hole $907 \mathrm{~A}$ are associated with reduced GRAPE bulk density and increased magnetic susceptibility values relative to mean values for these parameters. In the deeper portion of the hole, this situation is reversed, so that ash layers are generally associated with increased bulk density and magnetic susceptibility values relative to mean values for these intervals. Additional data for evaluating the GRAPE and magnetic susceptibility profiles from Hole $907 \mathrm{~A}$ are provided by studies of ash layers and ash-bearing sediments (see Lacasse et al., this volume; Werner et al., this volume).

The changes in GRAPE bulk density and magnetic susceptibility between the different geotechnical units of Hole 907A are best illustrated by comparing frequency distribution plots of these data (Fig. 4). Decreasing mean values of sediment bulk density are observed between geotechnical Units G-I, and G-III (i.e., mean values decrease from $1.68 \mathrm{~g} / \mathrm{cm} 3$ in Unit G-I, to 1.38 in Unit G-III), as a result of the increase in biogenic silica mentioned above. The lower bulk densities in geotechnical Unit G-II relative to Unit G-1 may be related to changes in the relative abundance and composition of clay minerals in the sediment, because high water content swelling clays, such as smectite, can lower the bulk density of sediments in the absence of significant quantities of biogenic silica. Increased amounts of volcanic ash in the lower Miocene, biosilica-dominated section of Hole 907A result in a bimodal distribution of GRAPE bulk density and magnetic susceptibility data in these APC cores, as seen in the frequency plots for geotechnical Unit G-IV (118.1-197.3 mbsf; see Fig. 4).

The correspondence between discrete measurements of bulk density and whole-core GRAPE bulk density measurements from Hole 907A (see Fig. 3) has been extended to develop a quantitative rela- 

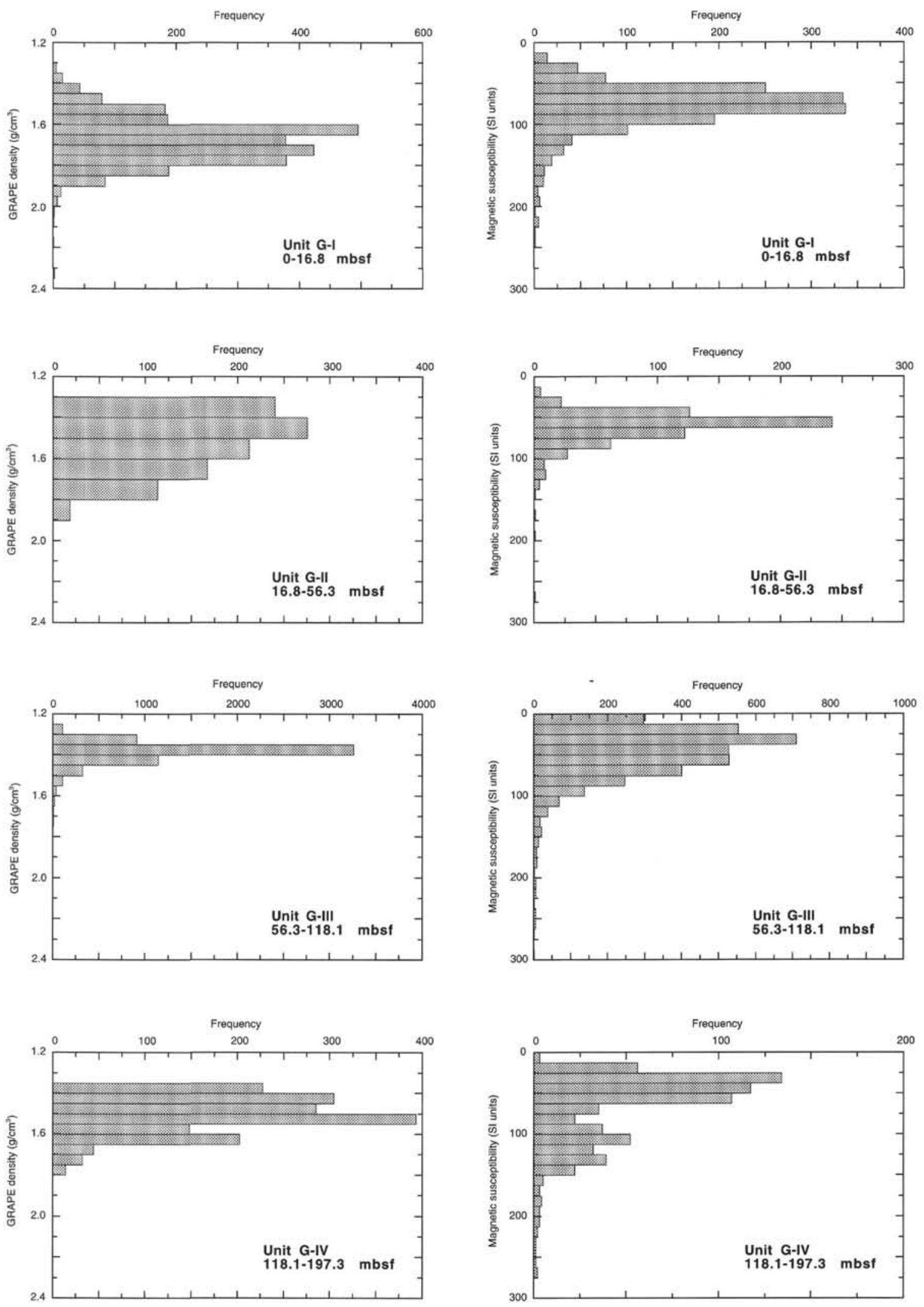

Figure 4. Frequency distribution of GRAPE bulk density and magnetic susceptibility measurements from the four geotechnical units described from Hole 907A (see Myhre, Thiede, Firth, et al., 1995). 
Table 2. Relationships between GRAPE bulk density and gravimetric determinations of index properties.

\begin{tabular}{|c|c|c|c|c|}
\hline Hole & Regression equation & $\mathrm{N}$ & $r^{2}$ & Type \\
\hline $907 \mathrm{~A}$ & Wet bulk density $=1.0258 \cdot($ GRAPE $)-0.059366$ & & 0.93 & linear \\
\hline $907 \mathrm{~A}$ & Dry density $=1.5983 \cdot($ GRAPE $)-1.684$ & & 0.95 & linear \\
\hline $907 \mathrm{~A}$ & Porosity $=158.9-56.096 \cdot($ GRAPE $)$ & & 0.92 & linear \\
\hline $907 \mathrm{~A}$ & Water content $(\%$ wet wt $)=157.29-69.6 \cdot($ GRAPE$)$ & & 0.94 & linear \\
\hline $907 \mathrm{~A}$ & Void ratio $=18.126 \cdot(\text { GRAPE })^{-4.4058}$ & & 0.82 & power \\
\hline $907 \mathrm{~A}$ & Water content $(\%$ dry $w t)=664.99 \cdot(\text { GRAPE })^{-4.4364}$ & & 0.90 & power \\
\hline $908 \mathrm{~A}$ & Wet bulk density $=0.9337 \cdot($ GRAPE $)+0.11988$ & 89 & 0.74 & linear \\
\hline $908 \mathrm{~B}$ & Wet bulk density $=0.83703 \cdot($ GRAPE $)+0.3168$ & 51 & 0.73 & linear \\
\hline $909 \mathrm{~A}$ & Wet bulk density $=1.1259 \cdot($ GRAPE $)-0.21783$ & 49 & 0.86 & linear \\
\hline $909 \mathrm{~B}$ & Wet bulk density $=1.1239 \cdot($ GRAPE$)-0.18966$ & 38 & 0.92 & linear \\
\hline $911 \mathrm{~A}$ & Wet bulk density $=1.1657 \cdot($ GRAPE $)-0.2643$ & 54 & 0.89 & linear \\
\hline $911 \mathrm{~B}$ & Wet bulk density $=1.1930 \cdot($ GRAPE $)-0.29159$ & 43 & 0.82 & linear \\
\hline $912 \mathrm{~A}$ & Wet bulk density $=0.99003 \cdot($ GRAPE $)+0.037761$ & 31 & 0.84 & linear \\
\hline $912 \mathrm{~B}$ & Wet bulk density $=1.1257 \cdot($ GRAPE $)-0.21351$ & 33 & 0.93 & linear \\
\hline
\end{tabular}

Notes: $\mathrm{N}=$ number of values used in regression, $\mathrm{r}^{2}=$ correlation coefficient, type $=$ equation style, wt $=$ weight.

tionship between GRAPE bulk density and gravimetric index properties for the entire sediment column (Table 2; Fig. 5). These relationships are useful for a variety of applications, such as estimating the dry bulk density of specific samples for use in calculating sediment accumulation rates.

\section{Fram Strait: Sites 908-909}

During Leg 151, five sites were cored in Fram Strait and on the Yermak Plateau (Fig. 6; Table 1). These sites record variations in sedimentary input from the Barents Sea and Svalbard region, and from continental margins surrounding the Arctic Ocean. These sites were cored to determine the age and lithologies of sediments on the Yermak Plateau and within Fram Strait, to explore the history of water-mass exchange between the Arctic Ocean and the NorwegianGreenland Sea, and to establish the timing and sedimentary processes since the opening of Fram Strait (Myhre, Thiede, Firth, et al., 1995).

Site 908 is located on the Hovgråd Ridge, in $1277 \mathrm{~m}$ of water, at the northward boundary of the Boreas Basin and the southern boundary of Fram Strait. Two holes were cored at this site using the APC and the extended core barrel (XCB). Site 909 is located on a small abyssal terrace directly north of Hovgråd Ridge and approximately in the middle of Fram Strait, at $2518 \mathrm{~m}$ below sea level (mbsl). Three holes were drilled at this site: Holes 909A and 909B were cored using the APC and XCB to sub-bottom depths of $92.5 \mathrm{mbsf}$ and 135.1 mbsf, respectively; Hole 909C was rotary cored to a depth of 1061.6 mbsf. The Pliocene to Pleistocene sections of Sites 908 and 909 are dominated by siliciclastic sediments, containing common dropstones and variable grain sizes. Sediments are defined as clayey mud, silty mud, and silty clay in lithologic Subunit IA (0-81.4 mbsf) at Site 908 , with silty clay, clayey silt, and fewer dropstones in Subunit IB (81.4-139.2 mbsf). At Site 909, lithologic Unit I (0-248.8 mbsf), contains abundant dropstones and consists of interbedded clay, silty clay, and clayey mud, with a minor component of calcareous nannofossils in the upper $50 \mathrm{mbsf}$.

The GRAPE bulk density profiles from Sites 908 and 909 (Fig. 7) show some distinct differences. The majority of the GRAPE bulk densities measured on cores from Site 908 are $>1.9 \mathrm{~g} / \mathrm{cm}^{3}$, whereas the GRAPE bulk densities measured on cores from Site 909 are generally $<1.9 \mathrm{~g} / \mathrm{cm}^{3}$. At both sites, there are generally increasing values of bulk density with increasing sub-bottom depth, as one would expect from the cumulative effects of increasing overburden on porosity reduction, but there are also highly variable density values over meter and centimeter scales, which may have some correspondence with changes in the relative inputs of sedimentary materials between glacial and interglacial climatic regimes. This will be evaluated in the ground-truth section of this paper.

Discrete measurements of bulk density were typically more abundant in the first hole cored at a given site, rather than in the second hole, because of the work load of the shipboard physical properties scientists. Clearly disturbed intervals of core, such as seen in the lowered GRAPE values in Core 151-909A-10H (see Fig. 7B), were not used in the process of calculating bulk density relationships. At Site 909 , there is a clear divergence of GRAPE density and discrete bulk density values below about $40 \mathrm{mbsf}$, although this is more pronounced in Hole 909B than in Hole 909A. The divergence in density values (GRAPE vs. discrete measurements) with increasing sub-bottom depth may be indicative of two different effects, namely, core disturbance and dewatering of the cores. Both of these effects may have been amplified by the higher methane content of the sediment at Site 909 relative to Site 908 (Myhre, Thiede, Firth, et al., 1995; Stein et al., 1995).

During Leg 151, small holes were drilled into the plastic core liners to allow the methane gas to escape when concentrations became elevated. When methane concentrations increased, the gas expansion may have significantly disrupted the sedimentary fabric and increased the porosity of the sediment within the core liner, thereby lowering measured GRAPE density values, which are based on the assumption that the core liner is completely filled with sediment and water. The holes drilled into the core liners may have also contributed to a progressive loss of water from the gassy cores with time, thereby further enhancing the divergence between the bulk density measurements made with the two methods.

\section{Yermak Plateau: Sites 910-912}

The Yermak Plateau, an arcuate marginal plateau extending for almost $400 \mathrm{~km}$ in a north-northwestward direction from the Svalbard continental shelf, is characterized by a narrow shelf with a wide slope having an irregular slope gradient. The southwestern portion of the plateau slopes gently toward the Spitsbergen and Molloy Fracture Zones in Fram Strait, but faulting and canyon cutting make the eastern flank of the plateau more blocky and rough (Myhre, Thiede, Firth, et al., 1995). Sites 910,911 , and 912 , form a bathymetric transect across the southern portion of the plateau (Fig. 6).

Site 910 is located on the southwestern crest of Yermak Plateau in $556 \mathrm{~m}$ of water. The core recovery at Site 910 was generally poor, because the APC was unable to penetrate below about 24 mbsf in Hole $910 \mathrm{~A}$, or below $18.6 \mathrm{mbsf}$ in Hole $910 \mathrm{D}$, as a result of the extremely stiff sediment encountered at these shallow sub-bottom depths. The bulk of the sediment recovered within the interval between 20 and $160 \mathrm{mbsf}$ at this site was recovered from Hole 910D. Post-cruise analyses of data from Site 910 and the results of X-ray investigations from Hole 910D (see Rack et al., this volume) are discussed in the ground-truth subsection of this paper.

Site 911 is located approximately $35 \mathrm{~km}$ to the northeast of Site 910 , in about $900 \mathrm{~m}$ of water, on the upper slope of the southeast portion of the Yermak Plateau. The sediments recovered at Site 911 

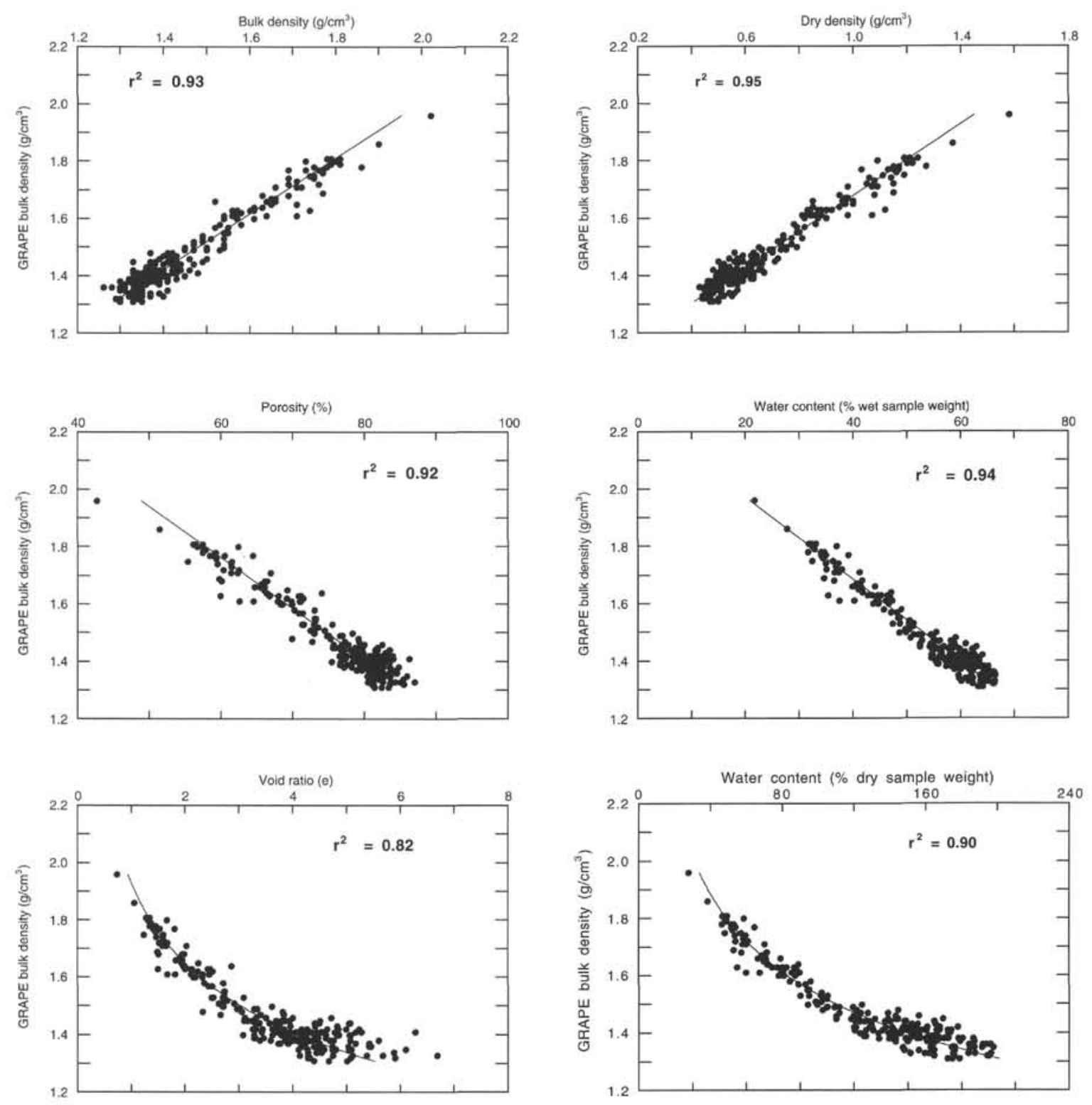

Figure 5. Relationships between GRAPE bulk density and index properties measurements, Hole 907A.

(Holes 911A, 911B, and 911C) are primarily unlithified, homogeneous, very dark gray clayey silts and silty clays of Quaternary and Pliocene age (Myhre, Thiede, Firth, et al., 1995). Dropstones are common, but biogenic particles are rare. The sediment texture in lithologic Subunit IA (0-380.4 mbsf) is highly variable and displays high-amplitude fluctuations of the sand-, silt-, and clay-size fractions. Light to heavy bioturbation is present throughout Subunit IA and black Fe-sulfide-filled burrows are common.

Site 912 is located $45 \mathrm{~km}$ to the southwest of Site 910 , on the southwestern edge of the Yermak Plateau in about $1037 \mathrm{~m}$ of water. Two lithologic subunits were identified at this site on the basis of changes in dropstone abundance (Myhre, Thiede, Firth, et al., 1995): Subunit IA ( $0-40 \mathrm{mbsf})$ consists of layers of silty mud and clayey mud interbedded with layers of silty clay; Subunit IB (40-209.1 mbsf) consists of silty clay and clayey silts, generally alternating with silty mud and clayey mud. The entire stratigraphic unit is interpreted to have been deposited in a hemipelagic environment with a large input of ice-rafted terrigenous materials at certain times.

GRAPE bulk density records from Sites 911 and 912 diverge with discrete bulk density measurements below about 60 mbsf in Hole
911A (38 mbsf in Hole 911B; see Fig. 8A), and below about $30 \mathrm{mbsf}$ in Holes 912A and 912B (see Fig. 8B). This effect is thought to be caused by high levels of methane in the sediment, which results in disturbance and dewatering of the sediment during gas expansion in the cores following recovery on deck. At Site 911, the concentrations of headspace methane are high throughout the sedimentary section, except for in the uppermost 25 mbsf. There is a large increase in headspace methane concentrations (from concentrations of 7-18 ppm to a value of $40,000 \mathrm{ppm}$ ) between 11.5 and $23 \mathrm{mbsf}$ at Site 912 , which persists downhole (Myhre, Thiede, Firth, et al., 1995; Stein et al., 1995).

\section{Bulk Density Relationships From Sites 908, 909, 911, and 912}

Variations in bulk density distributions between sites may result from, and provide information about, depositional and post-depositional processes, including: (1) differences in lithology between sites; (2) differences in sediment texture; (3) changes in accumulation 


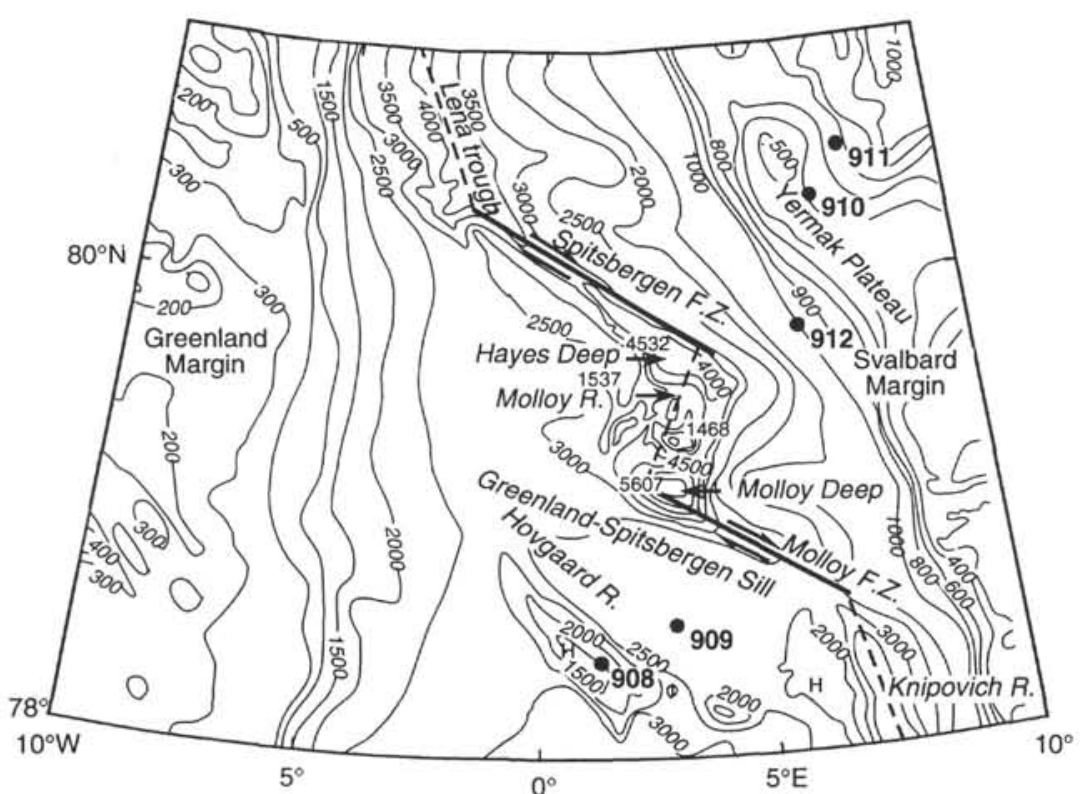

Figure 6. Bathymetric map of the Fram Strait region showing the locations of Sites 908-912 (from Perry et al., 1980, 1986; modified by Thiede et al., 1990). F.Z. = Fracture Zone.
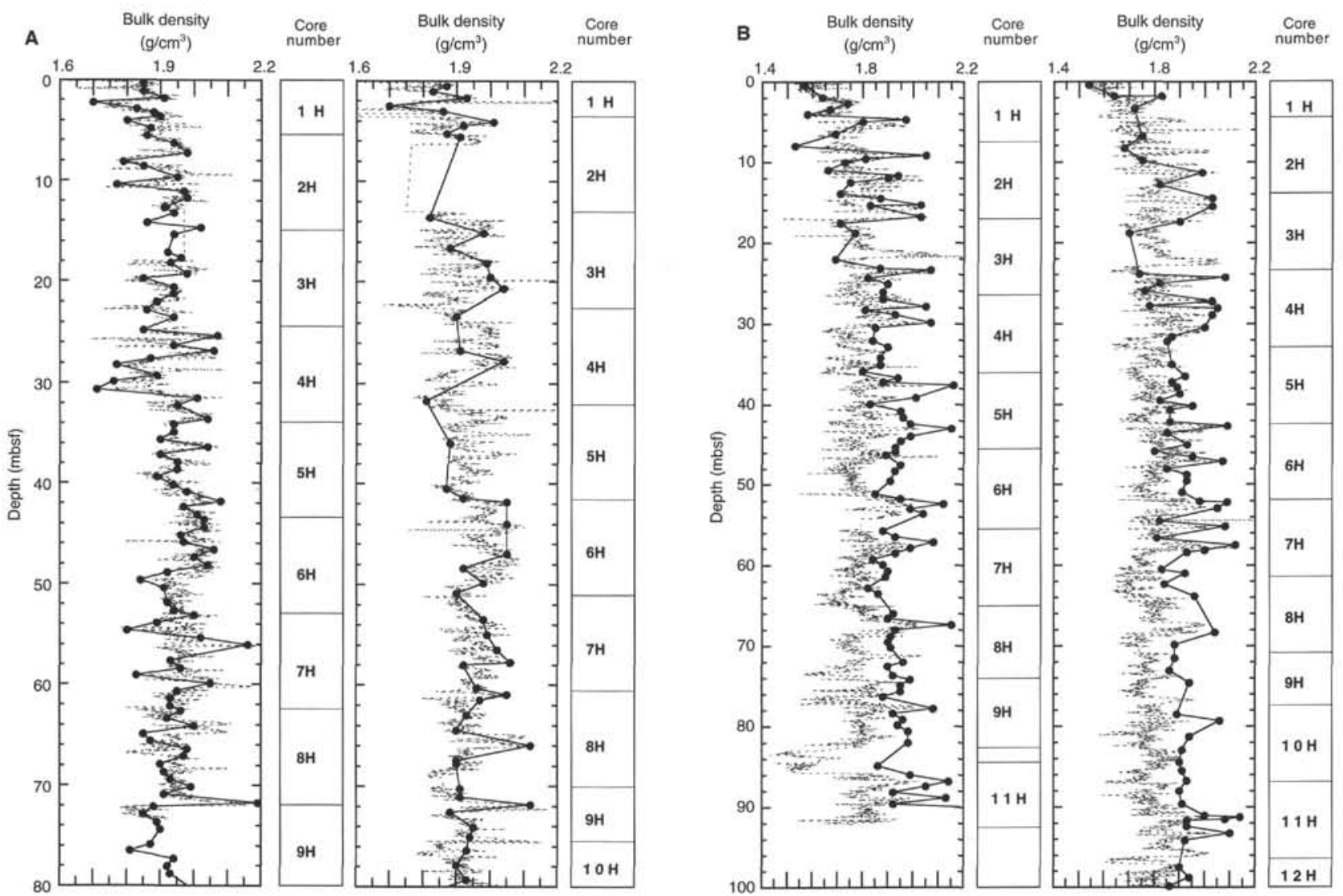

Figure 7. Comparison of GRAPE and discrete measurements of bulk density plotted vs. sub-bottom depth (mbsf). A. Holes 908A (left) and 908B (right). B. Holes 909A (left) and 909B (right). Note the change in density scale between Sites 908 and 909. 

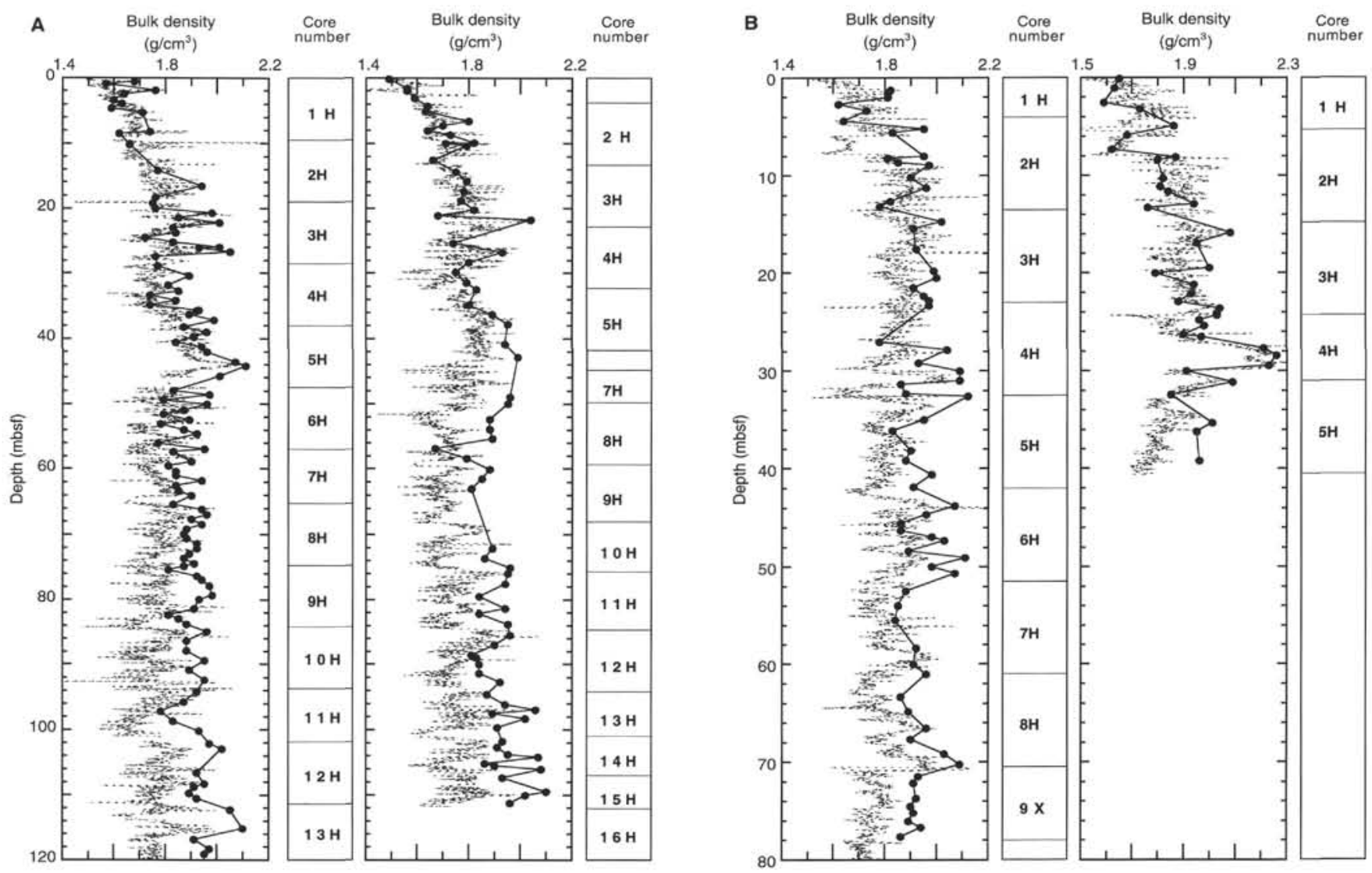

Figure 8. Comparison of GRAPE and discrete measurements of bulk density plotted vs. sub-bottom depth (mbsf). A. Holes 911A (left) and 911B (right). B. Holes $912 \mathrm{~A}$ (left) and 912B (right). Note the change in density scale for Hole 912B.

rates; (4) current-influenced winnowing of fine-grained material; and (5) core disturbance caused by gas expansion and dewatering.

After editing the data for quality, a minimum of 30 matched measurements from APC cores in each hole were used to develop quantitative relationships between discrete samples and GRAPE density measurements (see Table 2; Fig. 9). Gravimetric measurements of discrete samples agree fairly well with nondestructive GRAPE bulk density measurements, but the scatter in the data is greater at some sites (and between some holes) than at others. Linear regressions of the data from each hole result in reasonably high correlation coefficients, although Site 908 is somewhat anomalous and shows a lower correlation (between GRAPE density and discrete values) than was found at the other three sites studied.

The situation at Site 908 may be influenced by its location on the crest of the Hovgråd Ridge, where sediments may be winnowed by intermediate-water currents, creating a coarse sediment "lag-deposit". Cremer et al. (this volume), suggest that the coarse-grained fraction at Site 908 comprises a higher percentage of the bulk sediment and is better sorted than the coarse-grained fraction at Site 909. The significant lack of GRAPE bulk density values below $1.65 \mathrm{~g} / \mathrm{cm}^{3}$ at Site 908, and the skewness of the frequency plots shown in Figure $10 \mathrm{~A}$, supports the idea that winnowing may have removed the (lowdensity) fine-grained "tail" of the sediment accumulating at this site. Frequency distributions of GRAPE bulk densities from the other holes shown, generally have a more symmetrical distribution of values. The median GRAPE bulk density from Hole $908 \mathrm{~B}$ is $1.93 \mathrm{~g} / \mathrm{cm}^{3}$, which is significantly higher than any of the other holes (Fig. 11); for example, median GRAPE bulk density is $1.79 \mathrm{~g} / \mathrm{cm}^{3}$ for Hole $909 \mathrm{~B}$, $1.77 \mathrm{~g} / \mathrm{cm}^{3}$ for Hole $911 \mathrm{~A}$, and $1.81 \mathrm{~g} / \mathrm{cm}^{3}$ for Hole $912 \mathrm{~A}$. The bimo- dal distribution of GRAPE bulk density values in Hole 912B appears different from those of the other holes (Fig. 10A), caused by the recovery of a 3- to 4-m-thick, coarse-grained, unsorted, silty mud with abundant large dropstones in Core 151-912B-4H, which was only partially sampled in Hole 912A (see Fig. 8B).

When GRAPE bulk density values are plotted on the basis of geographic location (Fig. 11A), it is clearly seen that Sites 908 and 910 have the highest median values and that there are relative decreases in median GRAPE bulk density values at Sites 909, 911, and 912. When the sites are plotted according to their respective water depth (Fig. 11B), there is a different pattern in the distribution of median values, however, median values seem to decrease with increasing water depth, i.e., away from the crest of Yermak Plateau (Site 910) toward its slopes (Sites 911 and 912), and away from Hovgråd Ridge (Site 908) toward Fram Strait (Site 909). This geographic perspective may help one to understand the relative significance of ocean circulation and/or sea-ice patterns for sediment transport and accumulation in this region.

The frequency distributions of magnetic susceptibility data from these sites show a general trend of decreasing susceptibility values from the south toward the northeast across the study area (Fig. 10B). A plot of median values of magnetic susceptibility vs. geographic location shows that median values at Sites 910 and 911 are slightly higher that of Site 912 (Fig. 11A), which may suggest that additional or different sources of magnetic minerals become important to the northeast, across Yermak Plateau. When these data are plotted vs. water depth, the pattern is more complicated. Further study may show that the differences in these magnetic susceptibility patterns between sites are related to the geographic dispersal of detrital magnetic min- 

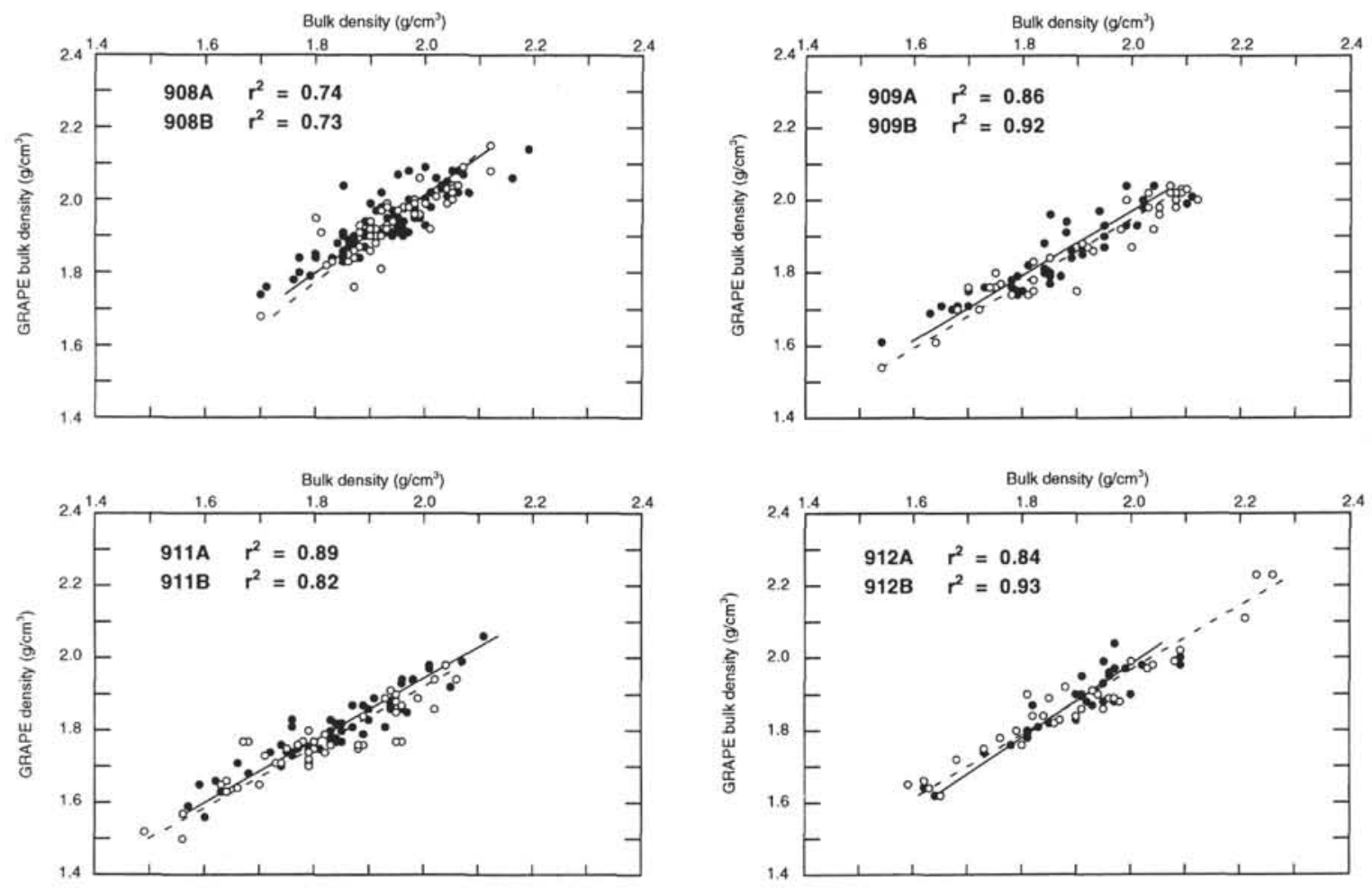

Figure 9. Relationships between GRAPE bulk density and discrete measurements of bulk density, Sites 908, 909, 911, and 912. Solid circles correspond to data from the "A" hole at each site. Open circles correspond to data from the "B" hole at each site.

erals by ice or current processes, or may indicate differences in the sedimentary geochemical environments between these sites.

\section{Development of Composite Depth Profiles}

Several ODP legs have used high-resolution measurements of GRAPE bulk density and magnetic susceptibility obtained from multiple holes at a single site to generate composite sections. The rationale behind the development of composite sections is discussed for example, by Ruddiman et al. (1987) and by Hagelberg et al. (1992, 1995). Briefly, the procedure aims to circumvent the well-documented phenomena of significant disturbance within cores and unrecovered sediment across core breaks by constructing a composite record consisting of discrete intervals taken from multiple holes at a single site. Given the presence of correlatable magnetic susceptibility and GRAPE bulk density fluctuations at a site, together with minimal core disturbance and offset core breaks, the method can in principle provide a continuous record.

In the case of Leg 151 sites, all of the above requirements were seldom met and to date we have only been able to construct composite sections for the upper parts of the APC-cored intervals at Sites 908, 909, and 911. In particular, between-hole correlations could only be made continuously and with confidence down to sub-bottom depths of about 60-80 mbsf at each site; gaps in coring, significant core disturbance caused by gas expansion, and the presence of abundant ice-rafted debris, all contributed to the lack of reliable correlations below these depths at each site.

The procedure we used for each of the sites (i.e., Sites 908, 909 . and 911) generally followed the method of Hagelberg et al. (1992) and consisted of the following: (1) the magnetic susceptibility records were correlated by eye, and the correlations were confirmed by reference to the GRAPE bulk density records - this clearly revealed the varying degrees of disturbance within cores, together with unrecovered intervals across core breaks; then, (2) based on the be- tween-hole correlations, successive cores were moved either upwards or downwards along a composite-depth scale, with magnetic susceptibility features at the extremities of cores being used as tie points. Within-core intervals from multiple holes were then spliced together to produce a stratigraphically complete, or near-complete record. The procedure was implemented graphically using a computer program ("splicer") kindly made available by Dr. P.B. deMenocal of Lamont-Doherty Earth Observatory.

The results for each of the three sites are shown in the form of (1) core offsets for each site (Tables 3-5), which enable ODP sub-bottom depths in each hole to be converted to composite depths and vice versa; (2) composite pathways for each site (Tables 6-8), which define the series of within-core intervals from specific holes that were combined to produce the composite sections - these can be used as guides for subsequent discrete sampling of the cores; and (3) plots of GRAPE bulk density and magnetic susceptibility for each hole, together with the composite records for these parameters, all plotted vs. composite depth in $\mathrm{m}$ (Site 908, Fig. 12; Site 909, Fig. 13; Site 911, Fig. 14).

\section{Ground-Truth Analyses of GRAPE Bulk Density and Magnetic Susceptibility Data}

\section{Hole 907A: Ash Investigations and Grain-Size Analyses}

Detailed studies of the major- and trace-element geochemistry of the tephra layers and disseminated ash-bearing sediments from Hole 907A have been made for the upper 90 mbsf (Lacasse et al., this volume), and for the deeper parts of the sedimentary sequence (Werner et al., this volume). Magnetic susceptibility and GRAPE bulk density data aided in the identification and sampling of more than 38 additional ash-bearing horizons in the deeper portion of the hole; these ashes were not previously identified during Leg 151 (Werner et al., this volume). Most peaks in magnetic susceptibility having values in excess of 120 SI units were found to mark ash-rich horizons (Fig. 3), 

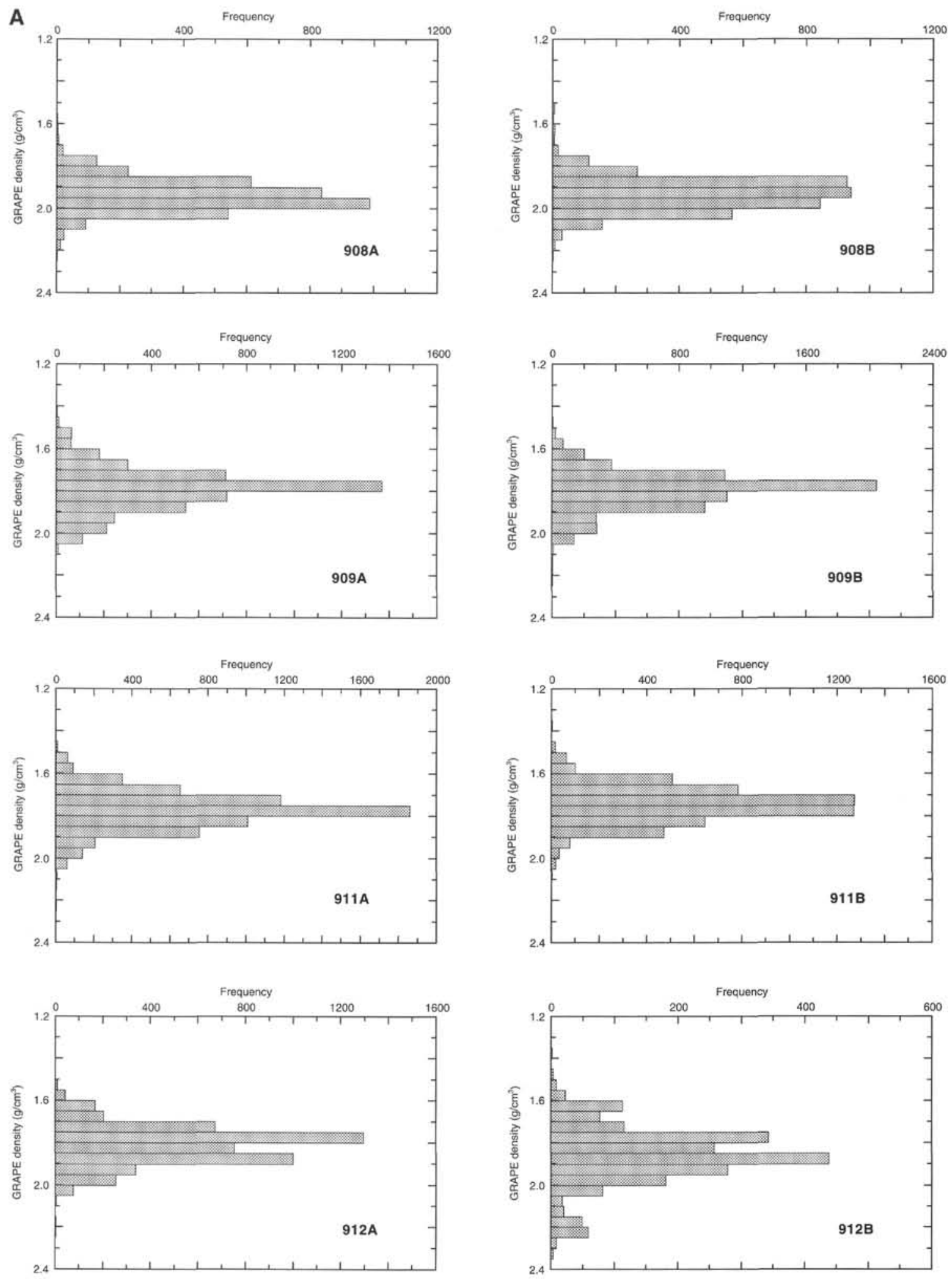

Figure 10. A. Frequency distributions of GRAPE bulk density measurements made on cores from adjacent holes at Sites 908, 909, 911, and 912. B. Frequency distributions of magnetic susceptibility measurements from the same holes as above.

although the magnitude of specific susceptibility peaks varied according to the composition of the ash, with basaltic ashes generally exhibiting larger susceptibility peaks than rhyolitic or trachytic ashes (Lacasse, et al., this volume; Werner et al., this volume).

Grain-size analyses were performed on bulk sediments from the interval between 38 and $62 \mathrm{mbsf}$ in Hole $907 \mathrm{~A}$, to investigate the na- ture of the observed alternation in "rough" and "smooth" surface texture in split cores from this interval (best observed in the photograph of Core 151-907A-6H; Myhre, Thiede, Firth, et al., 1995). Most of these data were not interpreted in time to be included in this volume (K. Black, pers. comm., 1995), however, we provide a brief glimpse of some of these data herein. The mean grain size of bulk-sediment 
B
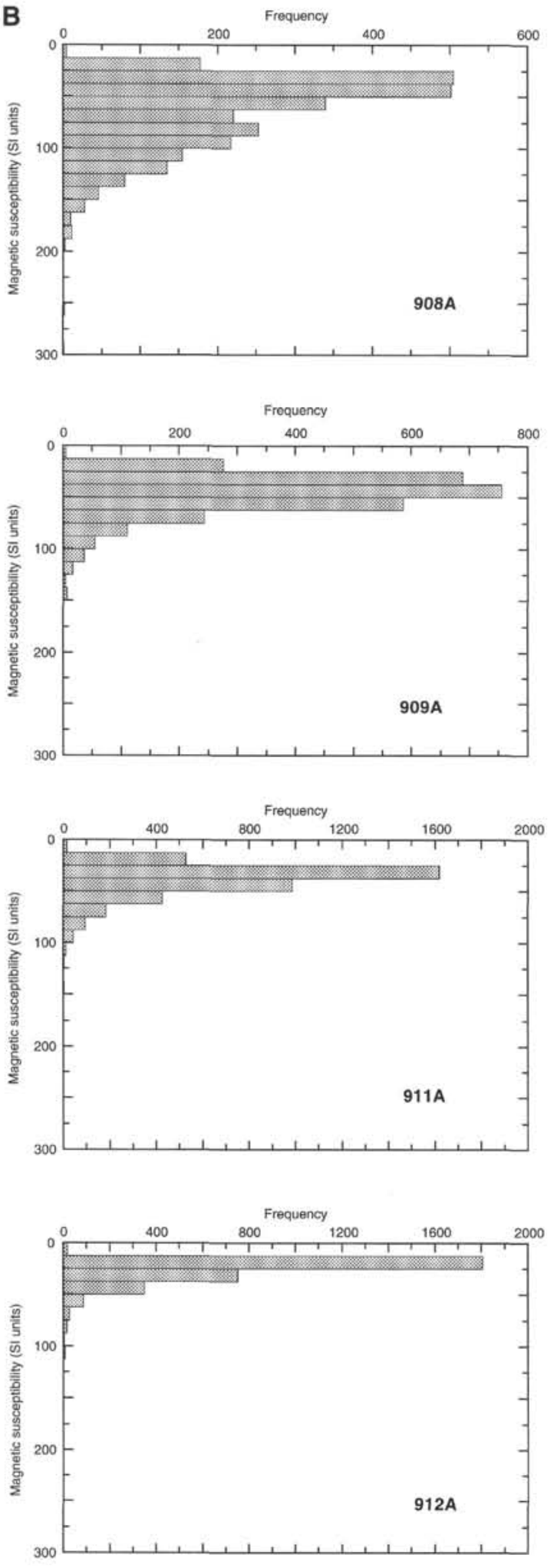
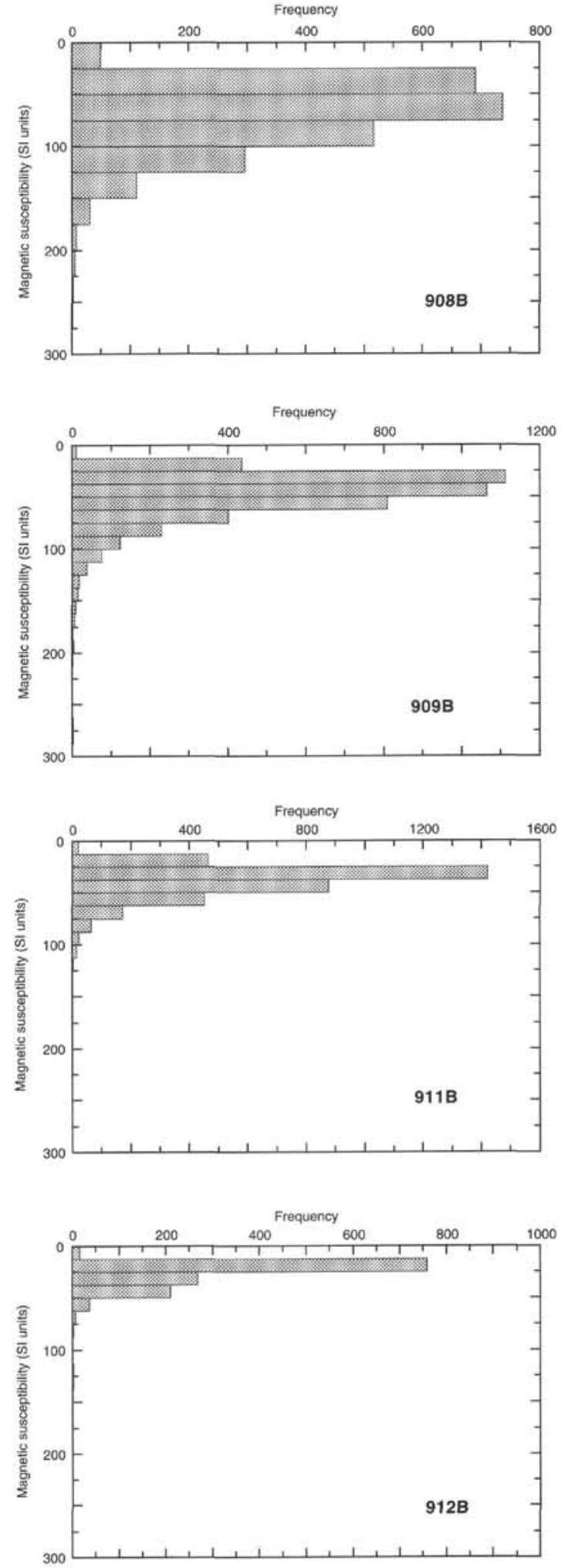

Figure 10 (continued).

samples is compared to extracted values of GRAPE bulk density and magnetic susceptibility that correspond to the same intervals as these samples (Fig. 15).

The positions of three ashes, labeled ash layer " $K$ " (18 cm thick), "L" ( 1 cm thick), and "M" (disseminated ash), by Lacasse, et al. (this volume), are shown in the magnetic susceptibility profile of Fig- ure 15. There is a significant amount of variability in the grain-size data, with large peaks in mean grain size between 50 and 54 mbsf, and below about $57 \mathrm{mbsf}$ in the low-density portion of the GRAPE record. Using the mean grain size, however, rather than the relative percentage of the coarse fraction, limits the usefulness of this particular comparison. The presence of additional, high-amplitude fluctua- 
A

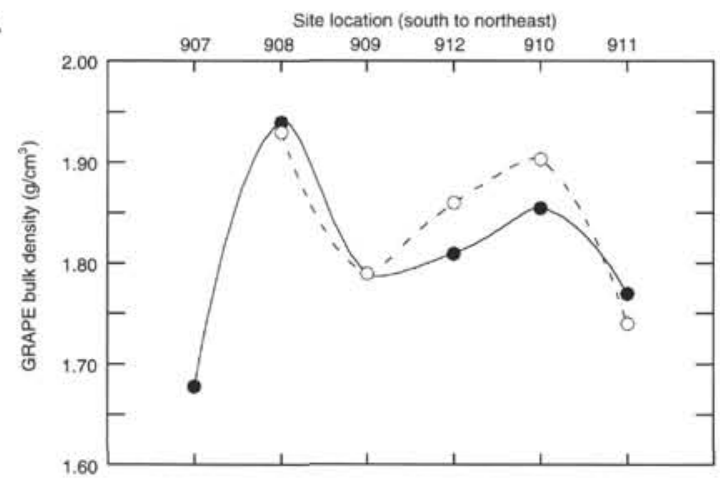

B

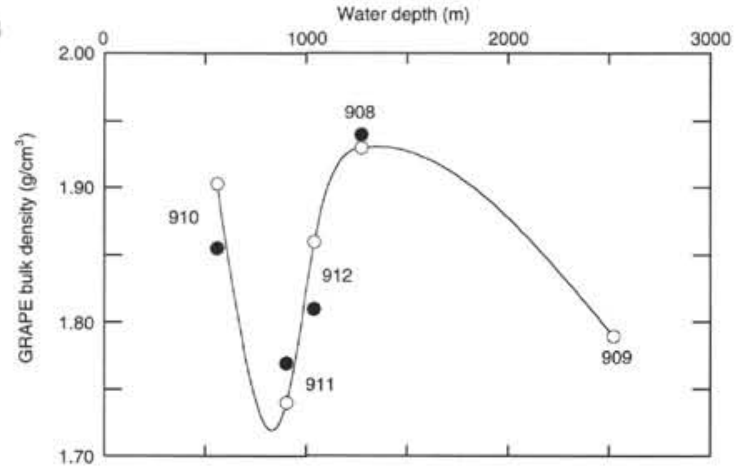

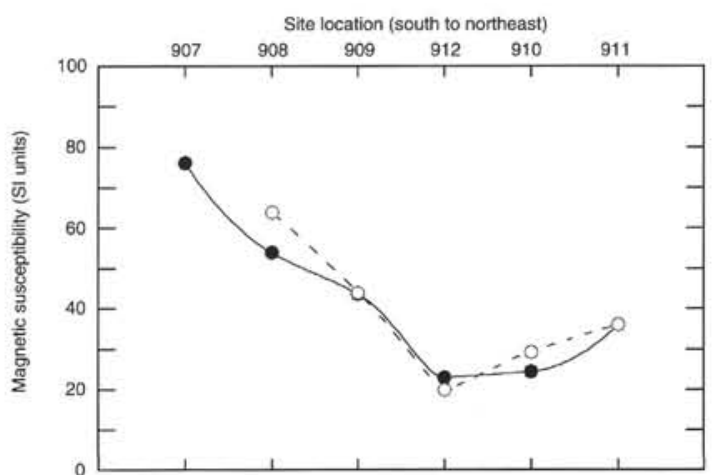

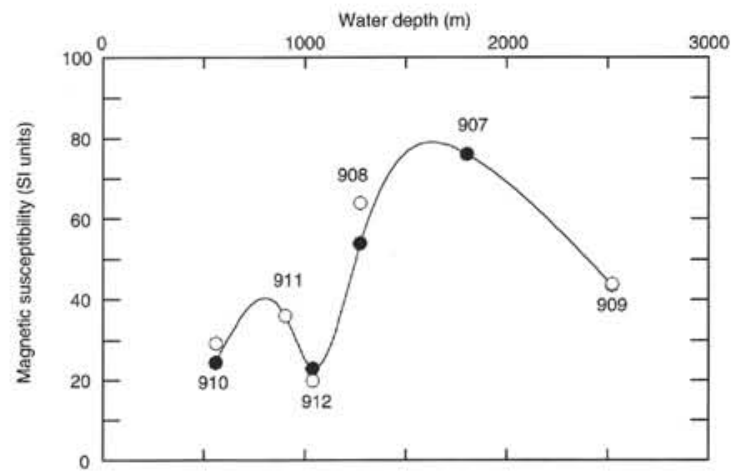

Figure 11. A. Median values of GRAPE bulk density and magnetic susceptibility measured on APC cores from Leg 151 sites. Sites are arranged according to their respective geographic location, from south to northeast across the Nordic Seas (solid circles = Holes 907A, 908A, 909A, 910C, 911A, and 912A; open circles $=$ Holes 908B, 909B, 910D, 911B, and 912B). B. Median values of GRAPE bulk density and magnetic susceptibility arranged according to increasing water depth (symbols same as above).

Table 3. Core offsets for Holes 908A and 908B.

\begin{tabular}{crrr}
\hline Core & $\begin{array}{c}\text { Depth } \\
(\mathrm{mbsf})\end{array}$ & $\begin{array}{c}\text { Offset } \\
(\mathrm{m})\end{array}$ & $\begin{array}{c}\text { Composite } \\
\text { depth } \\
(\mathrm{m})\end{array}$ \\
\hline $\begin{array}{c}151-908 \mathrm{~A}- \\
1 \mathrm{H}\end{array}$ & 0.00 & 0.0 & 0.00 \\
$2 \mathrm{H}$ & 5.40 & 0.0 & 5.40 \\
$3 \mathrm{H}$ & 14.90 & 1.0 & 15.90 \\
$4 \mathrm{H}$ & 24.40 & 1.3 & 25.70 \\
$5 \mathrm{H}$ & 33.90 & 2.1 & 36.00 \\
$6 \mathrm{H}$ & 43.40 & 2.6 & 46.00 \\
$7 \mathrm{H}$ & 52.90 & 2.6 & 55.50 \\
$8 \mathrm{H}$ & 62.40 & 3.4 & 65.80 \\
$151-908 \mathrm{~B}-$ & & & \\
$1 \mathrm{H}$ & 0.00 & 0.0 & 0.00 \\
$2 \mathrm{H}$ & 3.50 & 0.0 & 3.50 \\
$3 \mathrm{H}$ & 13.00 & 0.0 & 13.00 \\
$4 \mathrm{H}$ & 22.50 & 0.0 & 22.50 \\
$5 \mathrm{H}$ & 32.00 & 1.2 & 33.20 \\
$6 \mathrm{H}$ & 41.50 & 2.0 & 43.50 \\
$7 \mathrm{H}$ & 51.00 & 1.5 & 52.50 \\
$8 \mathrm{H}$ & 60.50 & 1.6 & 62.10 \\
\hline
\end{tabular}

tions in magnetic susceptibility and GRAPE bulk density in Figure 15 , in the absence of identified discrete ash layers, suggests that significant amounts of volcanic ash or igneous grains may be disseminated within discrete sedimentary intervals. This possibility should be evaluated as the resolution of sampling improves.

Fronval and Jansen (this volume) show an increase in the amount of ice-rafted debris/g of sediment in the interval from about 64 to 49 mbsf, which is within the depth interval of the data presented herein.
Table 4. Core offsets for Holes 909A and 909B.

\begin{tabular}{crrr}
\hline Core & $\begin{array}{c}\text { Depth } \\
(\mathrm{mbsf})\end{array}$ & $\begin{array}{c}\text { Offset } \\
(\mathrm{m})\end{array}$ & $\begin{array}{c}\text { Composite } \\
\text { depth } \\
(\mathrm{m})\end{array}$ \\
\hline $151-909 \mathrm{~A}-$ & & & \\
$1 \mathrm{H}$ & 0.00 & 0.0 & 0.00 \\
$2 \mathrm{H}$ & 7.50 & 0.0 & 7.50 \\
$3 \mathrm{H}$ & 17.00 & 1.9 & 18.90 \\
$4 \mathrm{H}$ & 26.50 & 1.9 & 28.40 \\
$5 \mathrm{H}$ & 36.00 & 2.6 & 38.60 \\
$6 \mathrm{H}$ & 45.50 & 3.2 & 48.70 \\
$7 \mathrm{H}$ & 55.50 & 2.2 & 57.70 \\
$8 \mathrm{H}$ & 65.00 & 3.2 & 68.20 \\
$9 \mathrm{H}$ & 74.00 & 3.7 & 77.70 \\
$151-909 \mathrm{~B}-$ & & & \\
$1 \mathrm{H}$ & 0.00 & -0.1 & -0.10 \\
$2 \mathrm{H}$ & 4.40 & 0.5 & 4.90 \\
$3 \mathrm{H}$ & 13.90 & 1.1 & 15.00 \\
$4 \mathrm{H}$ & 23.40 & 0.9 & 24.30 \\
$5 \mathrm{H}$ & 32.90 & 1.9 & 34.80 \\
$6 \mathrm{H}$ & 42.40 & 2.9 & 45.30 \\
$7 \mathrm{H}$ & 51.90 & 2.9 & 54.80 \\
$8 \mathrm{H}$ & 61.40 & 3.2 & 64.60 \\
$9 \mathrm{H}$ & 70.90 & 2.4 & 73.30 \\
$10 \mathrm{H}$ & 77.40 & 2.3 & 79.70 \\
\hline
\end{tabular}

Their results seems to correspond well with the observed trends of increasing GRAPE bulk density values and variable mean grain size shown in Figure 15. However, there are certainly other processes besides the accumulation of ice-rafted debris influencing the GRAPE bulk density within this interval, owing to the large increases in water content and porosity observed across this transition (Myhre, Thiede, 
Table 5. Core offsets for Holes 911A, 911B, and 911C.

\begin{tabular}{|c|c|c|c|}
\hline Core & $\begin{array}{l}\text { Depth } \\
\text { (mbsf) }\end{array}$ & $\begin{array}{c}\text { Offset } \\
\text { (m) }\end{array}$ & $\begin{array}{l}\text { Composite } \\
\text { depth } \\
\text { (m) }\end{array}$ \\
\hline $\begin{array}{l}151-911 \mathrm{~A}- \\
1 \mathrm{H} \\
2 \mathrm{H} \\
3 \mathrm{H} \\
4 \mathrm{H} \\
5 \mathrm{H} \\
6 \mathrm{H} \\
7 \mathrm{H} \\
8 \mathrm{H} \\
9 \mathrm{H} \\
10 \mathrm{H}\end{array}$ & $\begin{array}{r}0.00 \\
9.50 \\
19.00 \\
28.50 \\
38.00 \\
47.50 \\
57.00 \\
65.20 \\
74.70 \\
84.20\end{array}$ & $\begin{array}{l}0.50 \\
1.50 \\
1.55 \\
2.35 \\
1.85 \\
2.85 \\
4.24 \\
4.55 \\
4.49 \\
4.49\end{array}$ & $\begin{array}{r}0.50 \\
11.00 \\
20.55 \\
30.85 \\
39.85 \\
50.35 \\
61.24 \\
69.75 \\
79.19 \\
88.69\end{array}$ \\
\hline $\begin{array}{l}151-911 \mathrm{~B}- \\
1 \mathrm{H} \\
2 \mathrm{H} \\
3 \mathrm{H} \\
4 \mathrm{H} \\
5 \mathrm{H} \\
6 \mathrm{H} \\
7 \mathrm{H} \\
8 \mathrm{H} \\
9 \mathrm{H} \\
10 \mathrm{H}\end{array}$ & $\begin{array}{r}0.00 \\
3.80 \\
13.30 \\
22.80 \\
32.30 \\
41.80 \\
44.80 \\
49.80 \\
59.30 \\
68.00\end{array}$ & $\begin{array}{r}-0.20 \\
0.40 \\
0.60 \\
1.50 \\
1.83 \\
1.83 \\
6.63 \\
12.53 \\
13.63 \\
14.23\end{array}$ & $\begin{array}{r}-0.20 \\
4.20 \\
13.90 \\
24.30 \\
34.13 \\
43.63 \\
51.43 \\
62.33 \\
72.93 \\
82.23\end{array}$ \\
\hline $\begin{array}{c}151-911 C- \\
1 \mathrm{H} \\
2 \mathrm{H} \\
3 \mathrm{H} \\
4 \mathrm{H} \\
5 \mathrm{H} \\
6 \mathrm{H} \\
7 \mathrm{H} \\
8 \mathrm{H} \\
9 \mathrm{H} \\
10 \mathrm{H}\end{array}$ & $\begin{array}{r}0.00 \\
5.70 \\
15.20 \\
24.70 \\
34.20 \\
41.70 \\
51.20 \\
60.70 \\
69.50 \\
77.60\end{array}$ & $\begin{array}{l}0.00 \\
0.30 \\
0.50 \\
1.40 \\
2.40 \\
3.20 \\
3.25 \\
3.55 \\
5.05 \\
5.05\end{array}$ & $\begin{array}{r}0.00 \\
6.00 \\
15.70 \\
26.10 \\
36.60 \\
44.90 \\
54.45 \\
64.25 \\
74.55 \\
82.65\end{array}$ \\
\hline
\end{tabular}

Firth, et al., 1995). Above 45 mbsf, there are intermediate-amplitude changes in both GRAPE bulk density and magnetic susceptibility that generally show an inverse correlation (Fig. 16); below 45 mbsf, and generally over much of the rest of Hole $907 \mathrm{~A}$, there is a very poor correlation between these two parameters.

\section{Holes 908A and 909A: Textural and Compositional Ground-Truth Analyses}

The best existing opportunity to evaluate assumptions about the nature of GRAPE bulk density, as being representative of increases in the relative amounts of coarse-grained material in the sediment, was provided by the data produced by Wolf-Welling, et al. (this volume). The grain-size and compositional data from Holes 908A and 909A have been used to evaluate GRAPE bulk density signals on a sample by sample basis, using both, the relative textural changes identified by changes in the wt $\%$ of four coarse-grained subfractions, and their relation to compositional changes in the $125-$ to $500-\mu \mathrm{m}$ grain-size subfraction.

There is a gap in multi-sensor data from Hole 908A corresponding to several sections in Cores $151-908 \mathrm{~A}-2 \mathrm{H}$ and $3 \mathrm{H}$, where no data were available; a better comparison might be attempted using the composite record from Site 908, but this was not attempted in this paper. The fluctuations in coarse-grained subfractions from Hole 908A seem to correspond well to the major features of the GRAPE bulk density records, with most of the increases in GRAPE density being matched by increases in coarse-fraction wt $\%$ (Fig. 17; Table 9). However, closer quantitative examinations reveals the relatively poor correlation between these two groups of data (Fig. 18). The best correlation with the GRAPE data is provided by the coarse-grained subfraction from 63 to $125 \mu \mathrm{m}$. The compositional data from Hole 908A (Fig. 19) suggest a general correspondence between increases in the percentage of quartz grains and higher GRAPE density values, but the resolution of the data limits any detailed comparisons at this time.

The situation concerning data from Hole $909 \mathrm{~A}$ is quite different from that concerning data from Hole $908 \mathrm{~A}$, and reasonably good cor-
Table 6. Composite pathway for Site 908.

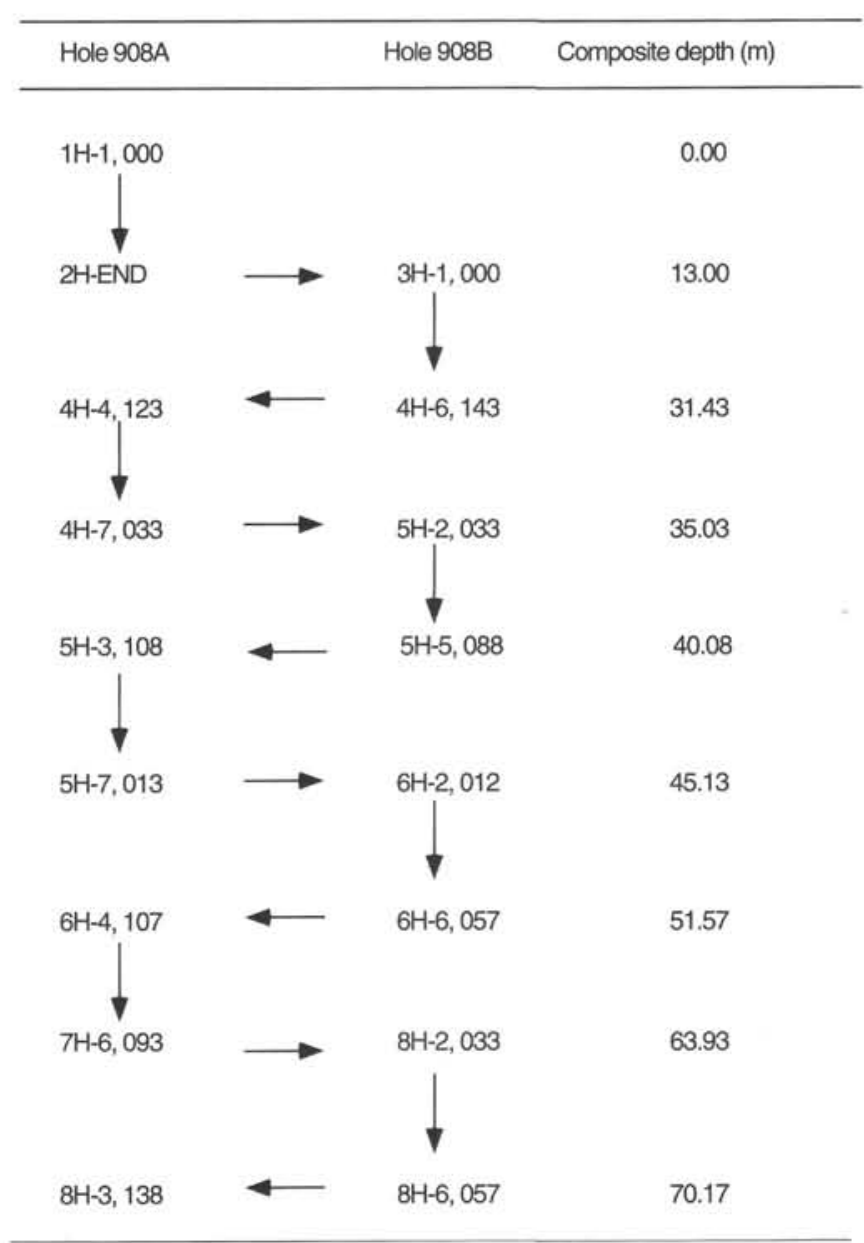

relations between GRAPE bulk density and textural data are possible. The continuity and quality of the GRAPE data from Hole 909A are very good, and the reader can quite easily see the agreement between the wt $\%$ fluctuations in almost all of the grain-size subfractions and the fluctuations in the GRAPE density record (Fig. 20; Table 9). The quantitative relationships developed between these data (Fig. 21) result in reasonably high correlation coefficients for all grain-size subfractions except one $(>500 \mu \mathrm{m})$, and provide a strong basis for future investigations along these lines as more data become available. The highest correlation is observed in the 125- to $500-\mu \mathrm{m}$ subfraction, which substantiates the assertion by various workers that this grainsize subfraction (of the coarse-fraction) is most representative of the terrigenous and biogenous components of the sediment (Henrich et al., 1989; Wolf and Thiede, 1991; Baumann et al., 1995, Wolf-Welling et al., this volume; among others). The compositional data from the 125- to 500- $\mu \mathrm{m}$ subfraction of Hole 909A show the dominance of quartz grains throughout most of the sequence (Fig. 22); large decreases in quartz in the upper part of the hole generally correspond to increases in planktonic and benthic foraminifers (Wolf-Welling et al., this volume). There is an interesting decrease in GRAPE bulk density values at about $30 \mathrm{mbsf}$, which seems to correspond to a similar decrease in both rock fragments and pyrite, and an increase in mica grains.

To test our understanding of the relationship between coarsegrained sediment accumulation and GRAPE bulk density fluctuations over glacial-interglacial cycles, we have constructed a graphical correlation of the upper $40 \mathrm{~m}$ of the composite GRAPE section at Site 909 (from the seafloor to slightly below the depth of the Brunhes/ Matuyama magnetic polarity reversal boundary in Hole 909A; 
Table 7. Composite pathway for Site 909.

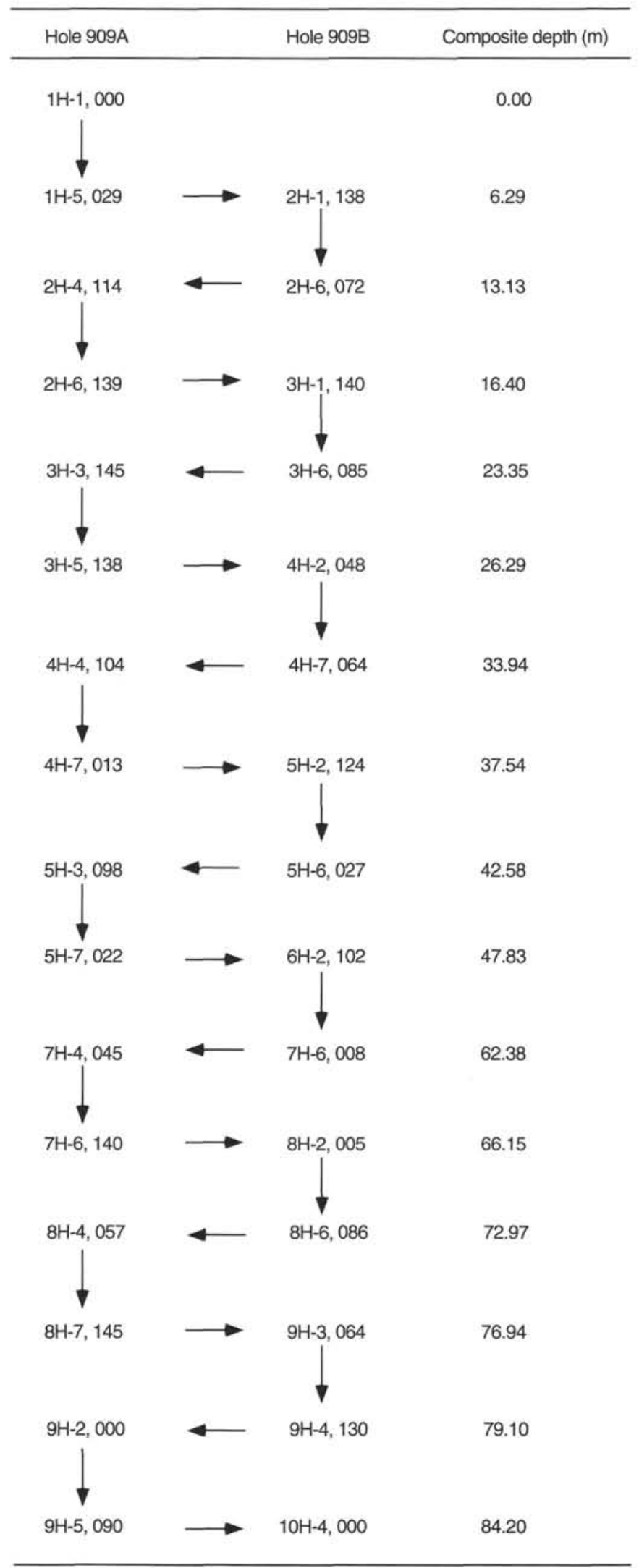

Myhre, Thiede, Firth, et al., 1995) with the stable oxygen-isotope tuned record from DSDP Site 607 (Ruddiman et al., 1989). We used the Site 607 record from the North Atlantic to provide an approximate age model for Site 909, based on the assumption that the GRAPE density peaks in Site 909 should correspond to heavier oxygen-isotope values in the record from Site 607 (Fig. 23). The two curves were matched using AnalySeries software provided by D. Palliard and L. Labeyrie.

Although these preliminary correlations require improvement, there is a remarkable agreement between the distribution of high-density peaks and glacial maxima, indicated by heavier oxygen-isotope values in the record of Site 607. Further refinements to this correlation may significantly improve our estimates of sedimentation rates at Site 909 in the absence of stable isotope data from this site. These initial correlations provide estimates of linear sedimentation rates within the Brunhes magnetic polarity interval at this site.

\section{Site 910: Combining Physical Properties, Multi-Sensor Data, and X-Ray Analyses of Cores}

Site 910 is located on the central inner Yermak Plateau, about 23 nmi to the northeast of Site 912 . It consists of silty clays and clayey silts with about $20 \%$ to $30 \%$ siliciclastic components and high dropstone abundance in lithologic Subunit IA (0-208.7 mbsf). Sediments are marked by distinct color banding in the upper $17 \mathrm{~m}$, but become more uniform in color below, where there is a distinct increase in the measured shear strength of the sediment (Myhre, Thiede, Firth, et al., 1995).

The major geotechnical characteristic of the sequence recovered in Hole $910 \mathrm{~A}$ is a large increase in sediment strength (measured by both the vane shear and the pocket penetrometer), beginning at about $16 \mathrm{mbsf}$ and increasing to maximum values at about $21 \mathrm{mbsf}$ (Fig. 24). Strengths determined with the pocket penetrometer were highly variable, and generally lower than vane shear strength values, because of sediment cracking during insertion of the penetrometer; however, below about $21 \mathrm{mbsf}$, the penetrometer measurements were continued because the spring on the vane shear device had exceeded its maximum value $(280-300 \mathrm{kPa})$. The lowermost sediments recovered in Hole 910A consisted of a stiff, coarse-grained diamicton that was interpreted to be overconsolidated, especially because the APC could not penetrate through this horizon. Hole $910 \mathrm{C}$ was cored using the rotary core barrel (RCB), but the resulting recovery of sediment in this hole was quite poor above about 200 mbsf (see Fig. 25).

A fourth hole (Hole 910D) was cored using the APC to $18.6 \mathrm{mbsf}$, and the XCB below to $160.6 \mathrm{mbsf}$; core recovery was $99.7 \%$ using the $\mathrm{APC}$ and $59.8 \%$ using the $\mathrm{XCB}$, as compared to less than $21 \%$ for the comparable interval in Hole 910C. Hole 910D was intended to provide samples for geotechnical studies to assess questions about the possible grounding of an ice mass on the crest of Yermak Plateau, and to evaluate other possible explanations for the unusual geotechnical results from this site. As part of the preliminary investigation of the Hole 910D sediments, whole-core X-ray images were acquired and have been interpreted to assess the number of clasts $>2 \mathrm{~mm}$ in size from successive 10-cm-long intervals of these cores (Rack et al., this volume). There is a significant increase in the number of clasts observed per 10-cm interval below about $16 \mathrm{mbsf}$ in Hole 910D (Fig. 25 ), although some intervals are still observed with low numbers of clasts (e.g., 17-18 mbsf). There is also a wide range of variability in the counts above $16 \mathrm{mbsf}$ that may turn out to correlate with cycles of ice advance and retreat around the margins of the Arctic Ocean (see fig. 12, in Rack et al., this volume). The frequency distribution of GRAPE bulk density in Hole 910D is skewed toward the higher values (Fig. 26) and has a median value of $1.90 \mathrm{~g} / \mathrm{cm}^{3}$ over $160 \mathrm{mbsf}$; only Hole 908B was found to have higher values of GRAPE bulk density $\left(\right.$ median $\left.=1.93 \mathrm{~g} / \mathrm{cm}^{3}\right)$. However, if only the upper $22 \mathrm{mbsf}$ of 
Table 8. Composite pathway for Site 911 .

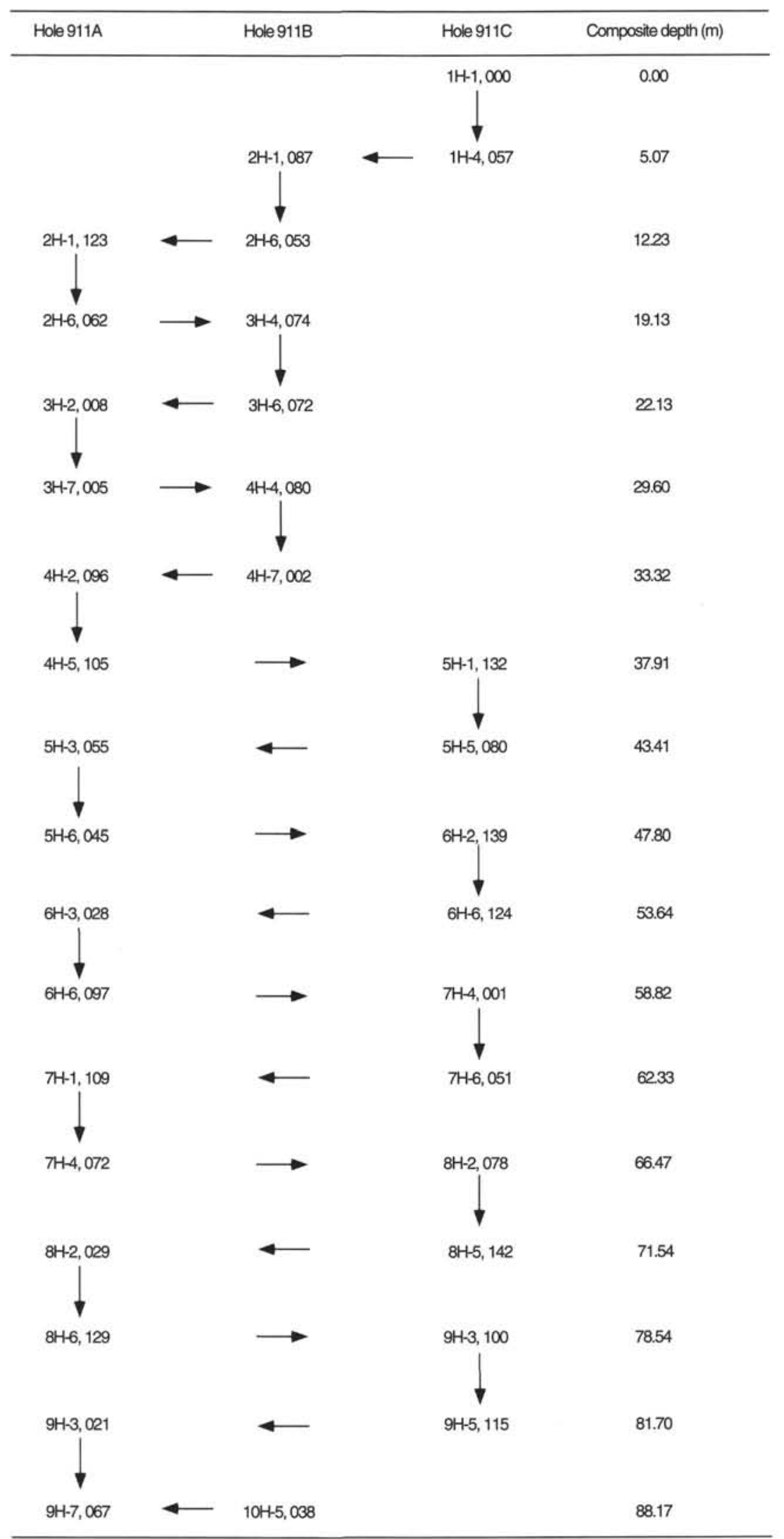




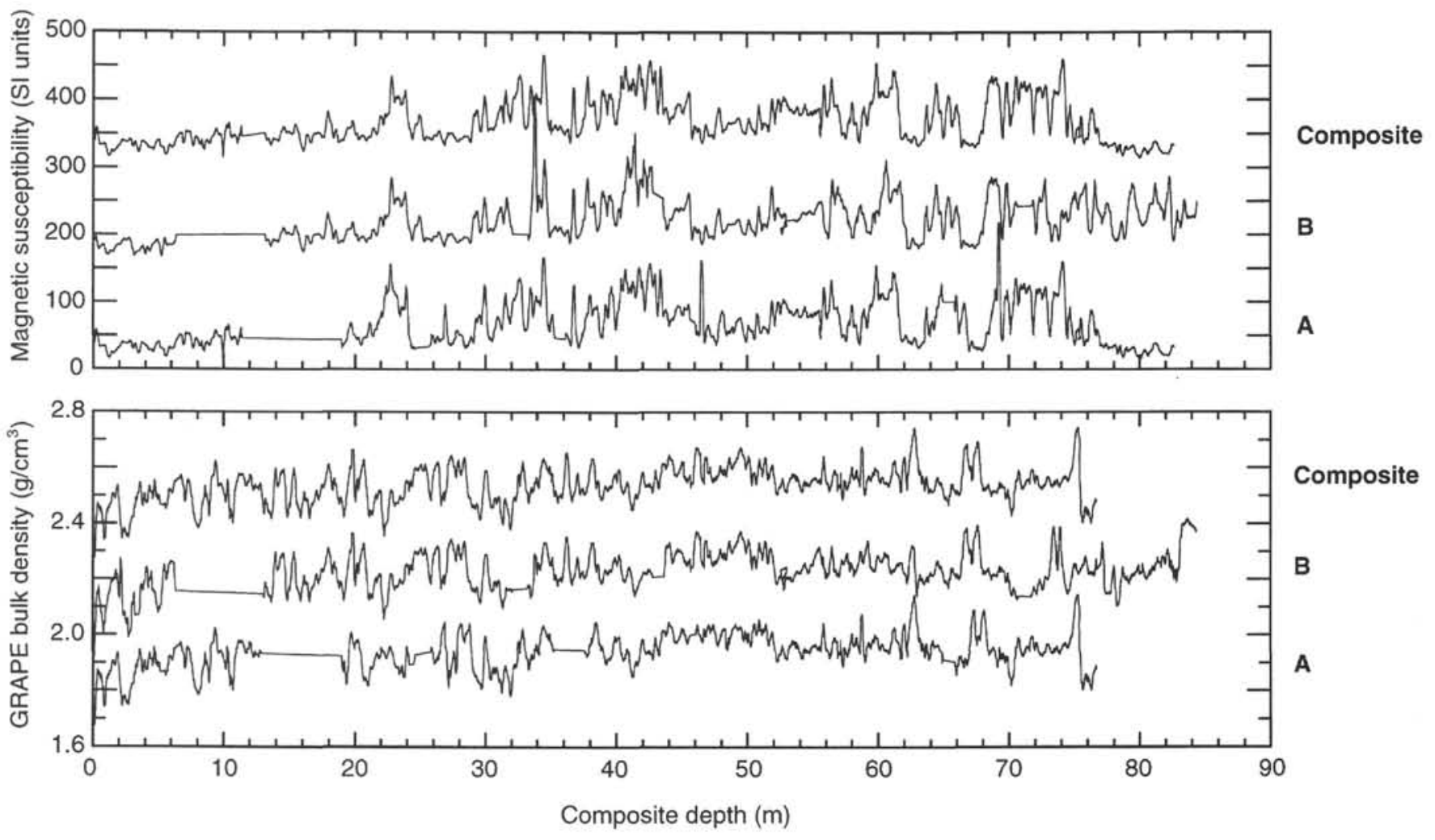

Figure 12. Profiles of magnetic susceptibility and GRAPE bulk density for Holes 908A and 908B, with their composite record, plotted vs. composite depth (m).

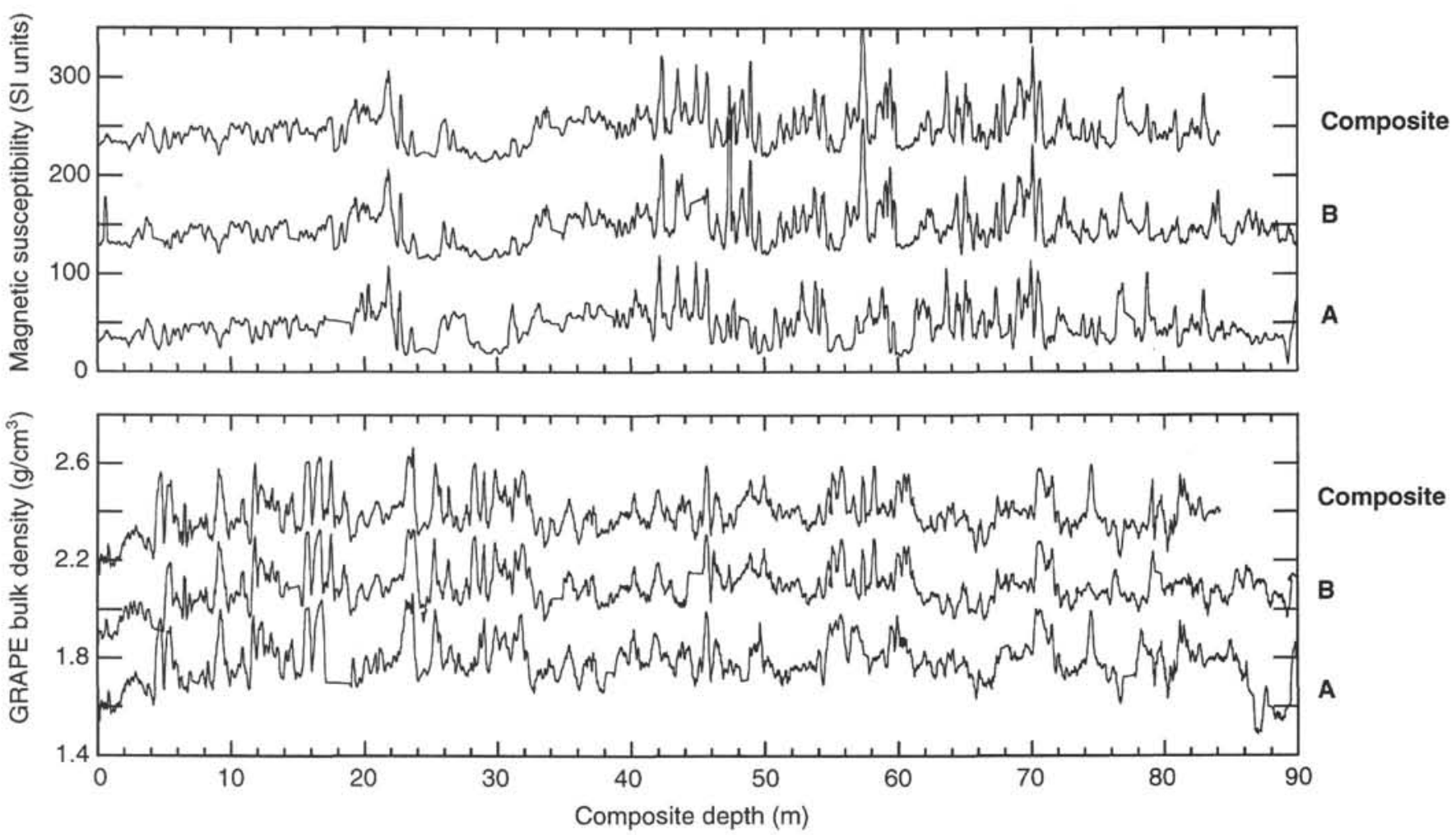

Figure 13. Profiles of magnetic susceptibility and GRAPE bulk density for Holes 909A and 909B, with their composite record, plotted vs. composite depth (m). 


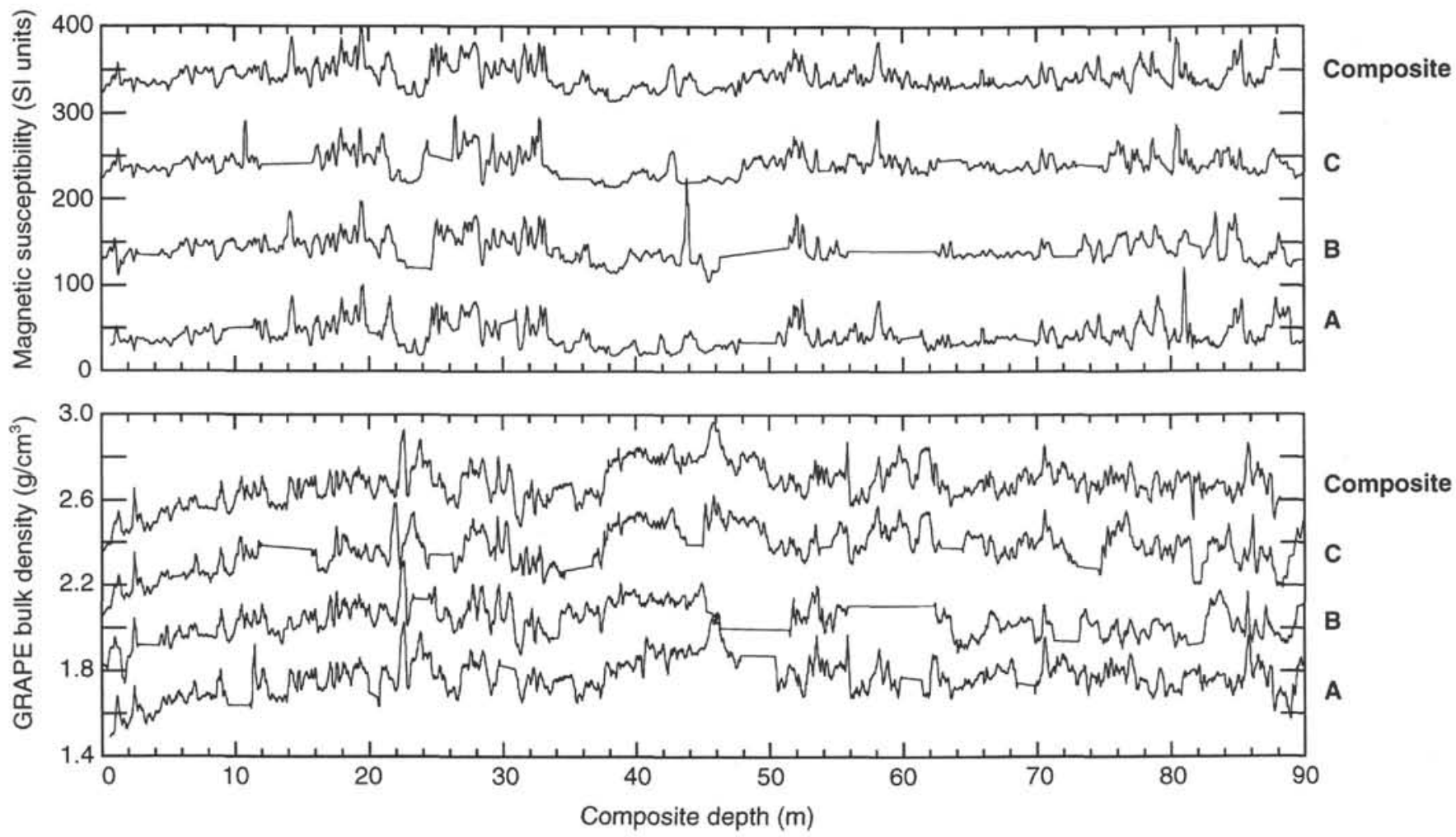

Figure 14. Profiles of magnetic susceptibility and GRAPE bulk density for Holes 911A, 911B, and 911C, with their composite record, plotted vs. composite depth (m).
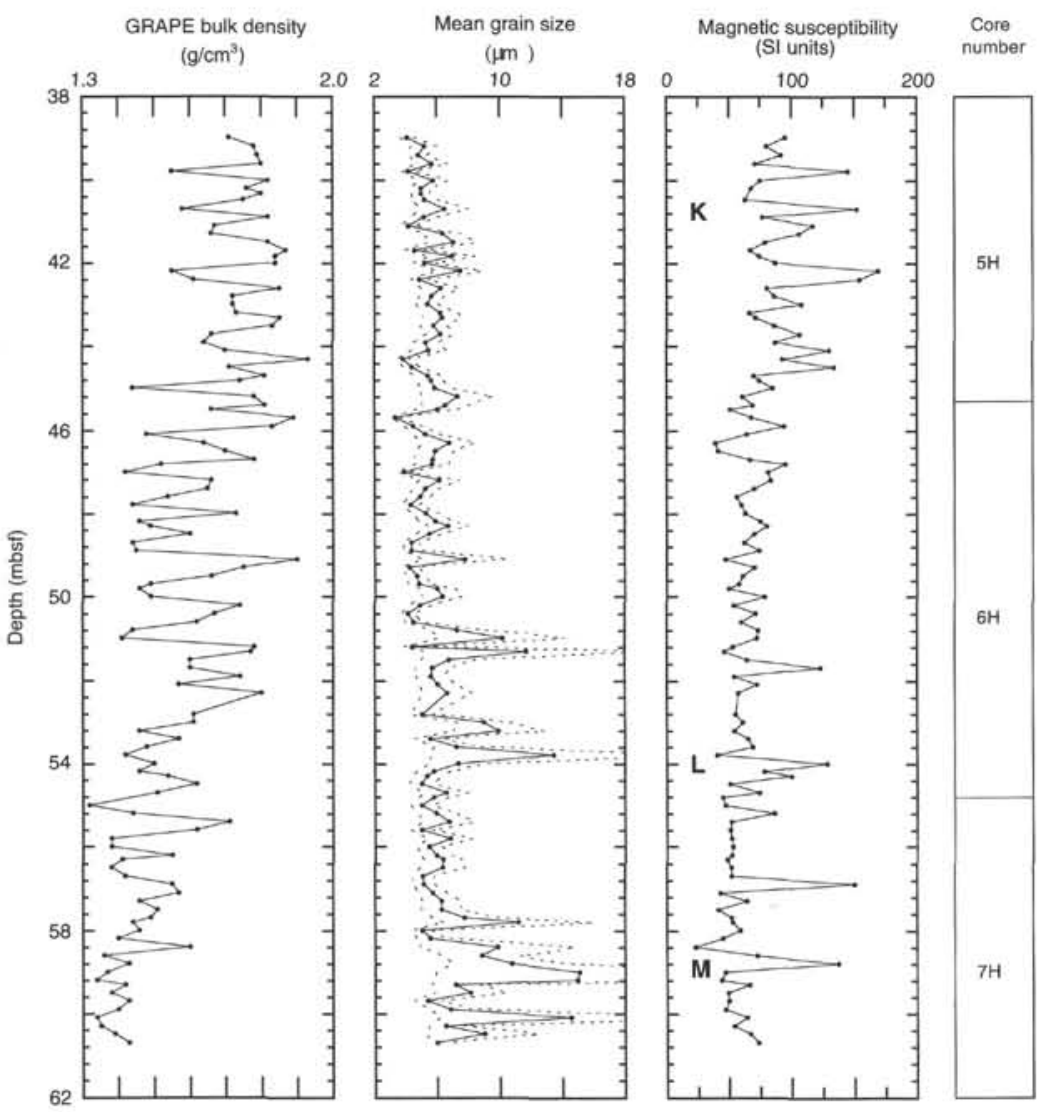

Figure 15. Comparison of GRAPE bulk density and magnetic susceptibility data and the mean grain size of sediment samples for the interval between 38 and 62 mbsf, Hole 907A. The dashed envelope surrounding the mean grain size (solid line) indicates one standard deviation around the mean. 

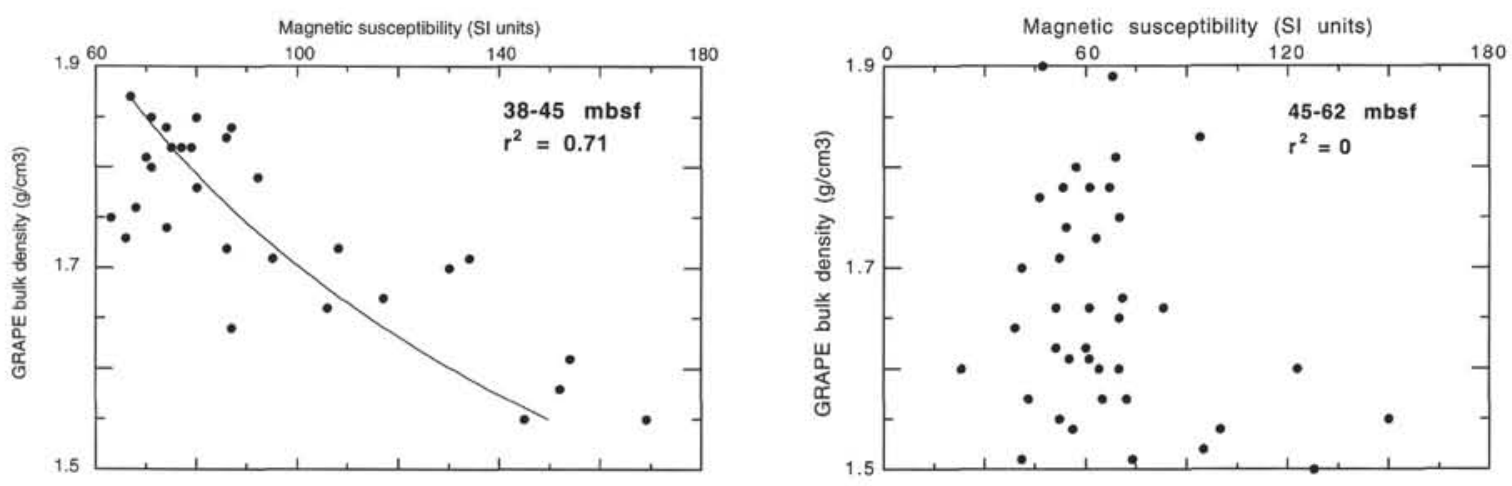

Figure 16. Interrelationships between magnetic susceptibility and GRAPE bulk density for two intervals from Hole 907A.

Hole $910 \mathrm{D}$ is used in the analysis, the median GRAPE bulk density value is increased to $1.97 \mathrm{~g} / \mathrm{cm}^{3}$.

Flower (this volume) presents stable isotopic results from Hole $910 \mathrm{~A}$ that suggest an age of approximately $620 \mathrm{ka}$ for the upper boundary of the stiff interval in that hole. This age falls within the range generally attributed to regional unconformities in the western Barents Sea (0.8 Ma, Vorren et al., 1991; 0.44 to 0.73 Ma, Sættem et al., 1992; $0.44 \mathrm{Ma}$, Hjelstruen et al., in press; Faleide et al., in press) and along the western Svalbard continental margin (Andersen et al., 1994) that represent a major change in glaciation, although exact dating of individual events along Svalbard are problematic at present (Solheim et al., in press). The change to highly burrowed sediment in Core 151-910D-10X, noted by Rack et al. (this volume), coincides with the return to higher sediment recovery in the deeper portions of this hole, after a 50-m interval of poor sediment recovery (Fig. 25). If the nannofossil age assignments from Hole 910C (Sato and Kameo, this volume) are directly applied to the equivalent depths in Hole 910D, then the highly bioturbated interval in Hole 910D can be assigned an approximate age of around 1.6-1.8 m.y., which, together with the upper age provide by Flower (this volume), suggests that the low recovery between Cores $151-910 \mathrm{D}-4 \mathrm{X}$ and $10 \mathrm{X}$ represents about 1 m.y. of sediment accumulation.

\section{CONCLUSIONS}

The following are some of the conclusions that can be drawn from this study:

1. The GRAPE bulk density and magnetic susceptibility measurements made on cores from Leg 151 are complex recorders of environmental parameters in dynamic environments such as the Nordic Seas, and these records need to be evaluated using a wide range of ground-truth data to fulfill their potential use across a wide range of paleoceanographic applications.

2. The relationships developed between near-continuous, nondestructive measurements made on whole-round cores and measurements of discrete index properties can be used to predict the properties of sediments located between measurements, to improve the resolution of stratigraphic studies, and to provide estimates of dry bulk density values for use in calculating sediment accumulation rates, among other applications.

3. The composite records of GRAPE bulk density and magnetic susceptibility provide an important resource for ongoing stratigraphic studies of individual Leg 151 sites and for regional correlations with other sites, and can be used in future investigations aimed at providing paleoceanographic and paleoclimatic insights regarding the evolution of North Atlantic glacial environments.
4. The GRAPE bulk density values from Hole 909A correspond to textural changes in grain-size distributions, which are linked to the transport of terrigenous sediment to the deep sea. The analysis of these records may lead to better estimates of sedimentation rates at this and other sites, and will provide the framework for coherent syntheses of data from Leg 151 and from other sites in the region.

5. The collaboration between sedimentologists and physical properties scientists can provide new opportunities to advance our understanding of the dynamics of marine environments and the records preserved in measurements of bulk physical and rock magnetic properties.

\section{ACKNOWLEDGMENTS}

We gratefully acknowledge the work of the captain, crew members, and technical staff of the JOIDES Resolution, who made this research possible. This is a contribution to the Climate System History and Dynamics (CSHD) Program, sponsored by the Natural Sciences and Engineering Research Council of Canada (NSERC) and the Atmospheric and Environment Service (AES).

\section{REFERENCES}

Aagaard, K., Darnall, C., Foldvik, A., Steg, M., and Tørresen, T., 1988. Fram Strait current measurements, 1985-1986. Dep. Oceanogr., Univ. of Bergen, Rep. 66.

Aagaard, K., Swift, J.H., and Carmack, E.C., 1985. Thermohaline circulation in the Arctic Mediterranean seas. J. Geophys. Res., 90:4833-4846.

Andersen, E.S., Solheim, A., and Elverhøi, A., 1994. Development of a glaciated Arctic continental margin: exemplified by the western margin of Svalbard. In Thurston, D.K., and Fujita, K. (Eds.), International Conference on Arctic Margins, Proceedings: Anchorage, AK (U.S. Dept. of the Interior), MMS 94-0040:155-160.

Baumann, K.-H., Lackschewitz, K.S., Mangerud, J., Spielhagen, R.F., WolfWelling, T.C.W., Henrich, R., and Kassens, H., 1995. Reflection of Scandinavian ice sheet fluctuations in Norwegian Sea sediments during the past 150,000 years. Quat. Res., 43:185-197.

Bischof, J., Koch, J., Kubisch, M., Spielhagen, R.F., and Thiede, J., 1990. Nordic seas surface ice drift reconstructions: evidence from ice rafted coal fragments during oxygen isotope stage 6. In Dowdeswell, J.A., and Scourse, J.D. (Eds.), Glaciomarine Environments: Processes and Sediments. Geol. Soc. Spec. Publ. London, 53:235-251.

Bloemendal, J., and deMenocal, P., 1989. Evidence for a change in the periodicity of tropical climate cycles at $2.4 \mathrm{Myr}$ from whole-core magnetic susceptibility measurements. Nature, 342:897-900.

Bloemendal, J., King, J.W., Hunt, A., deMenocal, P.B., and Hayashida, A., 1993. Origin of the sedimentary magnetic record at Ocean Drilling Program sites on the Owen Ridge, western Arabian Sea. J. Geophys. Res., 98:4199-4219. 
Bloemendal, J., Lamb, B., and King, J., 1988. Paleoenvironmental implications of rock-magnetic properties of late Quaternary sediment cores from the eastern equatorial Atlantic. Paleoceanography, 3:61-87.

Carmack, E., 1990. Large-scale physical oceanography of polar oceans. In Smith, W.O. (Ed.), Polar Oceanography, Part A: Physical Science: San Diego (Academic Press), 171-222.

deMenocal, P., Bloemendal, J., and King, J., 1991. A rock-magnetic record of monsoonal dust deposition to the Arabian Sea: evidence for a shift in the mode of deposition at $2.4 \mathrm{Ma}$. In Prell, W.L., Niitsuma, N., et al. Proc. ODP, Sci. Results, 117: College Station, TX (Ocean Drilling Program), 389-407.

Doh, S.-J., King, J.W., and Leinen, M., 1988. A rock-magnetic study of giant piston core LL4-GPC3 from the central North Pacific and its paleoceanographic implications. Paleoceanography, 3:89-111.

Eidvin, T., Jansen, E., and Riis, F., 1993. Chronology of Tertiary fan deposits off the western Barents Sea: implications for the uplift and erosion history of the Barents Shelf. Mar. Geol., 112:109-131.

Faleide, J.I., Solheim, A., Fiedler, A., Hjelstuen, B.O., Andersen, E.S., and Vanneste, K., in press. Late Cenozoic evolution of the western Barents Sea-Svalbard continental margin. Global Planet. Change, Spec. Iss., 318.

Hagelberg, T., Shackleton, N., Pisias, N., and Shipboard Scientific Party, 1992. Development of composite depth sections for Sites 844 through 854. In Mayer, L., Psias, N., Janecek, T., et al., Proc. ODP, Init. Repts., 138 (Pt. 1): College Station, TX (Ocean Drilling Program), 79-85.

Hagelberg, T.K., Pisias, N.G., Shackleton, N.J., Mix, A.C., and Harris, S., 1995. Refinement of a high-resolution, continuous sedimentary section for studying equatorial Pacific Ocean paleoceanography, Leg 138. In Pisias, N.G., Mayer, L.A., Janecek, T.R., Palmer-Julson, A., and van Andel, T.H. (Eds.), Proc. ODP, Sci Results, 138: College Station, TX (Ocean Drilling Program), 31-46.

Hempel, P., Mayer, L., Taylor, E., Bohrmann, G., and Pittenger, A., 1989. The influence of biogenic silica on seismic lithostratigraphy at ODP Sites 642 and 643, Eastern Norwegian Sea. In Eldholm, O., Thiede, J., Taylor, E., et al., Proc. ODP, Sci. Results, 104: College Station, TX (Ocean Drilling Program), 941-951.

Henrich, R., Wolf, T., Bohrmann, G., and Thiede, J., 1989. Cenozoic paleoclimatic and paleoceanographic changes in the Northern Hemisphere revealed by variability of coarse-fraction composition in sediments from the Vøring Plateau-ODP Leg 104 drill sites. In Eldholm, O., Thiede, J., Taylor, E., et al., Proc. ODP, Sci. Results, 104: College Station, TX (Ocean Drilling Program), 75-188.

Herbert, T.D., and Mayer, L.A., 1991. Long climatic time series from sediment physical property measurements. J. Sediment. Petrol., 61:10891108 .

Hjelstuen, B.O., Elverhøi, A., and Faleide, J.I., in press. Cenozoic erosion and sediment yield in the drainage area of the Storfjorden Fan. Global Planet. Change, Spec. Iss., 318.

Honjo, S., 1990. Particle fluxes and modern sedimentation in the polar oceans. In Smith, W.O., Jr. (Ed.), Polar Oceanography (Pt. B): Chemistry, Biology, and Geology: New York (Academic), 687-739.

Hunkins, K., 1990. A review of the physical oceanography of Fram Strait. In Pratt, L.J. (Ed.), The Physical Oceanography of Sea Straits: Dordrecht (Kluwer Acad. Publ.), 61-93.

Jansen, E., and Sjøholm, J., 1991. Reconstruction of glaciation over the past $6 \mathrm{Myr}$ from ice-borne deposits in the Norwegian Sea. Nature, 349:600603.

Kristoffersen, Y., 1990. On the tectonic evolution and paleoceanographic significance of the Fram Strait gateway. In Bleil, U., and Thiede, J. (Eds.), Geological History of the Polar Oceans: Arctic versus Antarctic. NATO ASI Ser., Ser. C, 308:63-76.

Manley, T.O., Bourke, R.H., and Hunkins, K.L., 1992. Near-surface circulation over the Yermak Plateau in northern Fram Strait. J. Mar. Sys., 3:107125 .

Mayer, L.A., 1979a. The origin and geologic setting of high-frequency acoustic reflectors in deep-sea carbonates [Ph.D. dissert.]. Univ. of California, San Diego.

1979b. Deep sea carbonates: acoustic, physical, and stratigraphic properties. J. Sediment. Petrol., 49:819-836.

1991. Extraction of high-resolution carbonate data for paleoclimate reconstruction. Nature, 352:148-150.

Mayer, L.A., Jansen, E., Backman, J., and Takayama, T., 1993. Climatic cyclicity at Site 806: the GRAPE record. In Berger, W.H., Kroenke, L.W., Mayer, L.A., et al., Proc. ODP, Sci. Results, 130: College Station, TX (Ocean Drilling Program), 623-639.
Mayer, L.A., Shipley, T.H., Theyer, F., Wilkens, R.H., and Winterer, E.L., 1985. Seismic modeling and paleoceanography at Deep Sea Drilling Project Site 574. In Mayer, L., Theyer, F., Thomas, E., et al., Init. Repts. DSDP, 85: Washington, (U.S. Govt. Printing Office), 947-970.

Mienert, J., and Bloemendal, J., 1989. A comparison of acoustic and rockmagnetic properties of equatorial Atlantic deep-sea sediments: paleoceanographic implications. Earth Planet. Sci. Lett., 94:291-300.

Mienert, J., and Chi, J., 1995. Astronomical time-scale for physical property records from Quaternary sediments of the northern North Atlantic. Geol. Rundsch., 84:67-88.

Mienert, J., Curry, W.B., and Sarnthein, M., 1988. Sonostratigraphic records from equatorial Atlantic deep-sea carbonates: paleoceanographic and climatic relationships. Mar. Geol., 83:9-20.

Muench, R.D., McPhee, M.G., Paulson, C.A., and Morison, J.H., 1992. Winter oceanographic conditions in the Fram Strait -Yermak Plateau region. J. Geophys. Res., 97:3469-3483.

Myhre, A.M., and Eldholm, O., 1988. The western Svalbard Margin $\left(74^{\circ}-\right.$ $80^{\circ}$ N). Mar. Pet. Geol., 5:134-156.

Myhre, A.M., Thiede, J., Firth, J.V., et al., 1995. Proc. ODP, Init. Repts., 151: College Station, TX (Ocean Drilling Program).

Perry, R.K., Fleming, H.S., Cherkis, N.Z., Feden, R.H., and Vogt, P.R., 1980. Bathymetry of the Norwegian-Greenland and Western Barents Sea: Washington, D.C. (Naval Research Laboratory).

Perry, R.K., Fleming, H.S., Weber, J.R., Kristoffersen, Y., Hall, J.K., Grantz, A., Johnson, G.L., Cherkis, N.Z., and Larsen, B., 1986. Bathymetry of the Arctic Ocean: Washington, D.C. (Naval Research Laboratory) (scale 1:6,000,000).

Pisias, N.G., Mayer, L.A., and Mix, A.C., 1995. Paleoceanography of the eastern equatorial Pacific during the Neogene: synthesis of Leg 138 drilling results. In Pisias, N.G., Mayer, L.A., Janecek, T.R., Palmer-Julson, A., and van Andel, T.H. (Eds.), Proc. ODP, Sci. Results, 138: College Station, TX (Ocean Drilling Program), 5-21.

Rack, F.R., 1993. A geologic perspective on the Miocene evolution of the Antarctic Circumpolar Current system. Tectonophysics, 222:397-415.

Rack, F.R., Janecek, T.J., Erba, E., Fenner, J., and Gee, J.S., 1995. Synthesis of terrigenous accumulation rates and biostratigraphic studies at sites in the northwestern Pacific Ocean, with comparisons to adjacent regions of the Pacific Gyre. In Haggerty, J.A., Premoli Silva, I., Rack, F., and McNutt, M.K. (Eds.), Proc. ODP, Sci. Results, 144: College Station, TX (Ocean Drilling Program), 691-736.

Rack, F.R., and Palmer-Julson, A., 1992. Sediment microfabric and physical properties record of late Neogene Polar Front migration, Site 751. In Wise, S.W., Jr., Schlich, R., et al., Proc. ODP, Sci. Results, 120: College Station, TX (Ocean Drilling Program), 179-205.

Rack, F.R., and Pittenger, A., 1992. Geotechnical stratigraphy of Neogene sediments: Maud Rise and Kerguelen Plateau. In Kennett, J.P., and Warnke, D.A. (Eds.), The Role of the Southern Ocean and Antarctica in Global Change. Am. Geophys. Union, Antarct. Res. Ser., 60:203-230.

Riis, F., and Fjeldskaar, W., 1992. On the magnitude of Late Tertiary and Quaternary erosion and its significance for the uplift of Scandinavia and the Barents Sea. In Larsen, R.M., Brekke, H., Larsen, B.T., and Talleraas, E. (Eds.), Structural and Tectonic Modelling and its Application to Petroleum Geology. Norw. Petrol. Soc. Spec. Publ., 1:163-185.

Robinson, S.G., 1986. The late Pleistocene paleoclimatic record of North Atlantic deep-sea sediments revealed by mineral-magnetic measurements. Phys. Earth Planet. Inter, 42:22-47.

Robinson, S.G., and Maslin, M.A, 1995. Magnetic susceptibility variations in Pleistocene deep-sea sediments of the N.E. Atlantic: implications for ice rafting and paleocirculation at the last glacial maximum. Paleoceanography, 10:221-250.

Robinson, S.G., and McCave, I.N., 1994. Orbital-forcing of bottom-current enhanced sedimentation on Feni Drift, N.E. Atlantic, during the MidPleistocene. Paleoceanography, 9:943-972.

Ruddiman, W.F., Cameron, D., and Clement, B.M., 1987. Sediment disturbance and correlation of offset holes drilled with the hydraulic piston corer: Leg 94. In Ruddiman, W.F., Kidd, R.B., Thomas, E., et al., Init. Repts. DSDP, 94 (Pt. 2): Washington (U.S. Govt. Printing Office), 615634.

Ruddiman, W.F., Raymo, M.E., Martinson, D.G., Clement, B.M., and Backman, J., 1989. Pleistocene evolution: Northern Hemisphere ice sheets and North Atlantic Ocean. Paleoceanography, 4:353-412.

Sættem, J., Poole, D.A.R., Ellingsen, L., and Sejrup, H.P., 1992. Glacial geology of outer Bjørnøyrenna, southwestern Barents Sea. Mar: Geol., 103:15-51. 
Shackleton, N.J., Crowhurst, S., Hagelberg, T., Pisias, N.G., and Schneider, D.A., 1995. A new late Neogene time scale: application to Leg 138 sites. In Pisias, N.G., Mayer, L.A., Janecek, T.R., Palmer-Julson, A., and van Andel, T.H. (Eds.), Proc. ODP, Sci. Results, 138: College Station, TX (Ocean Drilling Program), 73-101.

Shackleton, N.J., and Shipboard Scientific Party, 1992. Sedimentation rates: toward a GRAPE density stratigraphy for Leg 138 carbonate sections. In Mayer, L., Pisias, N., Janecek, T., et al., Proc. ODP, Init. Repts., 138 (Pt. 1): College Station, TX (Ocean Drilling Program), 87-91.

Solheim, A., Anderson, E.S., Elverhøi, A., and Fiedler, A., in press. Late Cenozoic depositional history of the western Svalbard continental shelf, controlled by subsidence and climate. Global Planet. Change, Spec. Iss., 318.

Stein, R., Brass, G., Graham, D., Pimmel, A., and the Shipboard Scientific Party, 1995. Hydrocarbon measurements at Arctic Gateways sites (ODP Leg 151). In Myhre, A.M., Thiede, J., Firth, J.V., et al., Proc. ODP, Init. Repts., 151: College Station, TX (Ocean Drilling Program), 385-395.
Thiede, J., Clark, D.L., and Herman, Y., 1990. Late Mesozoic and Cenozoic paleoceanography of the northern polar oceans. In Grantz, A., Johnson, L., and Sweeney, J.F. (Eds.), The Arctic Ocean Region. Geol. Soc. Am., Geol. of North Am. Ser., L:427-458.

Vinje, T.E, and Finneskaasa, Ø., 1986. The ice transport through Fram Strait. Norsk Polarinst. Skr., 186.

Vorren, T.O., Richardsen, G., and Knutsen, S.-M., 1991. Cenozoic erosion and sedimentation in the western Barents Sea. Mar. Petrol. Geol., 8:317340 .

Wolf, T.C.W., and Thiede, J., 1991. History of terrigenous sedimentation during the past 10 m.y. in the North Atlantic (ODP Legs 104 and 105 and DSDP Leg 94). Mar. Geol., 101:83-102.

Date of initial receipt: 5 January 1996

Date of acceptance: 10 May 1996

Ms 151SR-149 


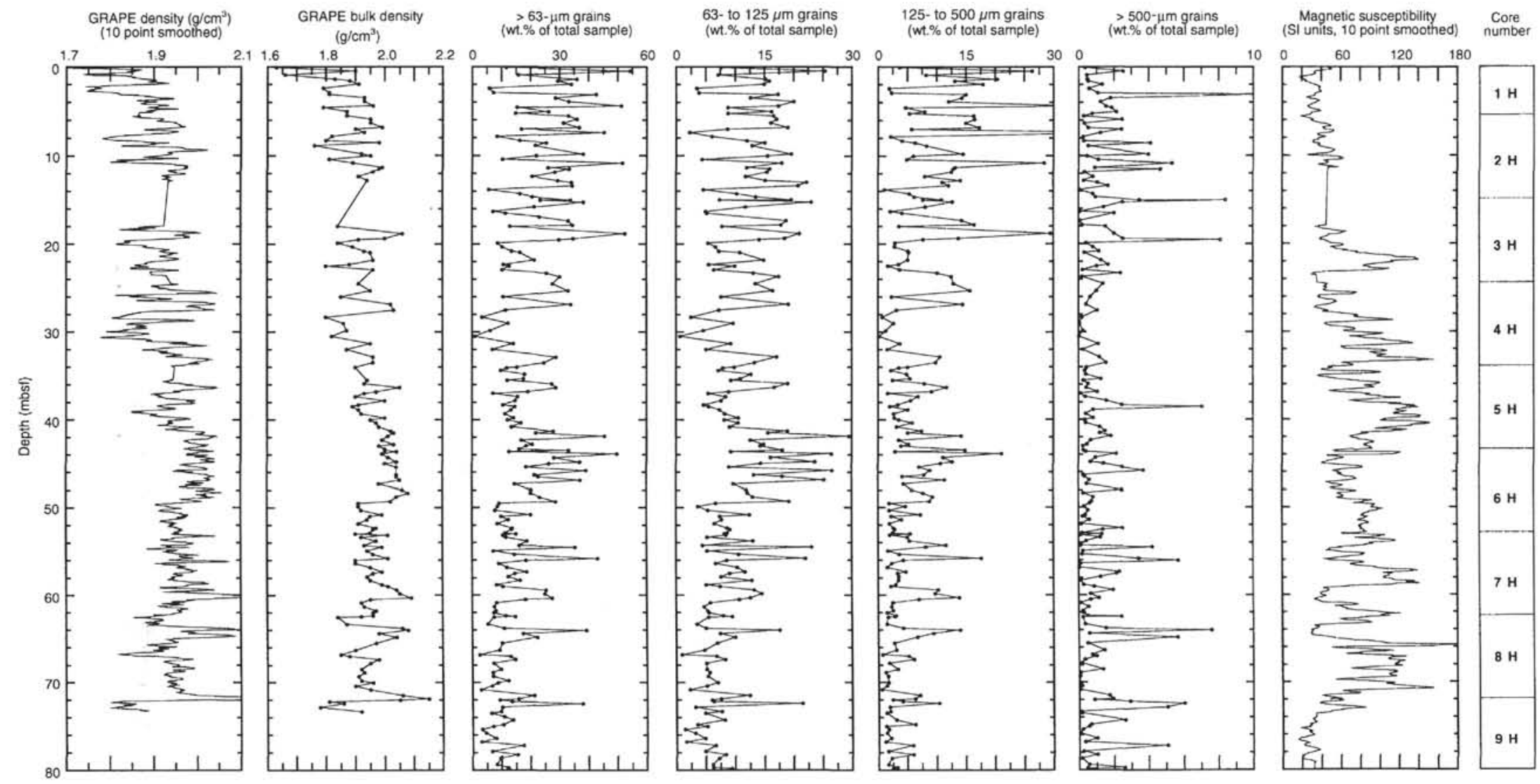

Figure 17. Comparisons between GRAPE bulk density and the results of textural analyses of discrete sediment samples from Hole 908A (data from Wolf-Welling et al., this volume). Note that GRAPE bulk density values shown in the second plot from the left correspond to the sediment samples used for textural analyses. 
Table 9. Relationships between GRAPE bulk density and grain-size data, Holes 908A and 909A.

\begin{tabular}{clcc}
\hline Hole & \multicolumn{1}{c}{ Regression equation } & $\mathrm{r}^{2}$ & Type \\
\hline $908 \mathrm{~A}$ & $>63 \mu \mathrm{m}(\mathrm{wt} \%)=0.023202^{*}(\mathrm{GRAPE})^{9.6922}$ & 0.23 & power \\
$908 \mathrm{~A}$ & $63-125 \mu \mathrm{m}(\mathrm{wt} \%)=0.019159^{*}(\mathrm{GRAPE})^{9.2534}$ & 0.25 & power \\
$908 \mathrm{~A}$ & $125-250 \mu \mathrm{m}(\mathrm{wt} \%)=0.0014294^{*}(\mathrm{GRAPE})^{11.804}$ & 0.16 & power \\
$908 \mathrm{~A}$ & $250-500 \mu \mathrm{m}(\mathrm{wt} \%)=0.0010926^{*}(\mathrm{GRAPE})^{9.7562}$ & 0.14 & power \\
$908 \mathrm{~A}$ & $125-500 \mu \mathrm{m}(\mathrm{wt} \%)=0.0020768^{*}(\mathrm{GRAPE})^{11.531}$ & 0.16 & power \\
$908 \mathrm{~A}$ & $>500 \mu \mathrm{m}(\mathrm{wt} \%)=0.011537^{*}(\mathrm{GRAPE})^{5.8039}$ & 0.02 & power \\
$909 \mathrm{~A}$ & $>63 \mu \mathrm{m}(\mathrm{wt} \%)=0.004197^{*}(\mathrm{GRAPE})^{12.949}$ & 0.62 & power \\
$909 \mathrm{~A}$ & $63-125 \mu \mathrm{m}(\mathrm{wt} \%)=0.0012264^{*}(\mathrm{GRAPE})^{13.618}$ & 0.56 & power \\
$909 \mathrm{~A}$ & $125-250 \mu \mathrm{m}(\mathrm{wt} \%)=0.00029393^{*}(\mathrm{GRAPE})^{15.025}$ & 0.56 & power \\
$909 \mathrm{~A}$ & $250-500 \mu \mathrm{m}(\mathrm{wt} \%)=0.0010816^{*}(\mathrm{GRAPE})^{11.136}$ & 0.38 & power \\
$909 \mathrm{~A}$ & $125-500 \mu \mathrm{m}(\mathrm{wt} \%)=0.00075711^{*}(\mathrm{GRAPE})^{13.999}$ & 0.58 & power \\
$909 \mathrm{~A}$ & $>500 \mu \mathrm{m}(\mathrm{wt} \%)=9.3003^{*}(\mathrm{GRAPE})-14.583$ & 0.09 & linear \\
& & &
\end{tabular}

Notes: Type $=$ equation style, $\mathrm{r}^{2}=$ correlation coefficient, $\mathrm{wt}=$ weight.
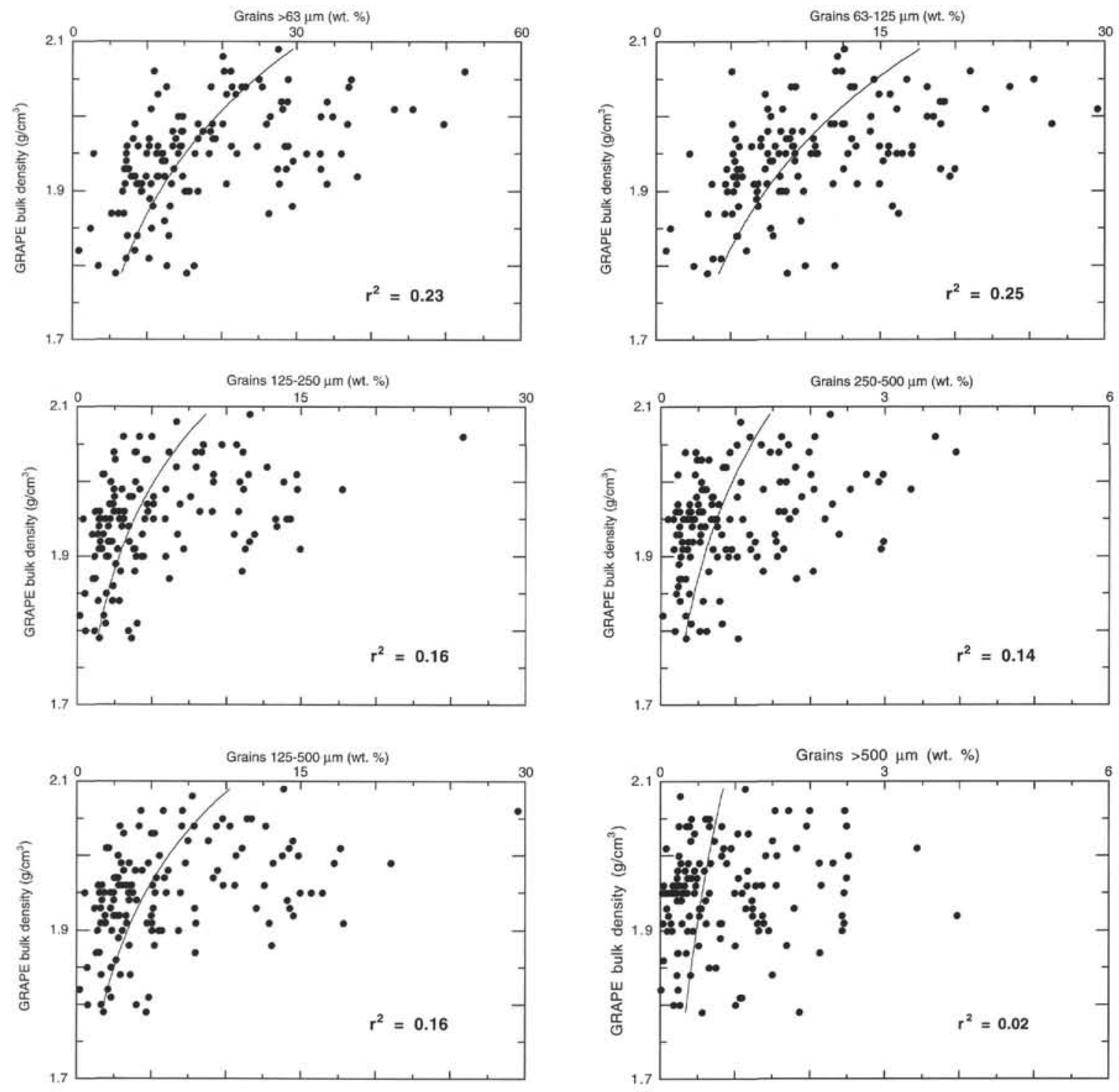

Figure 18. Interrelationships between GRAPE bulk density and textural data, Hole 908A. 


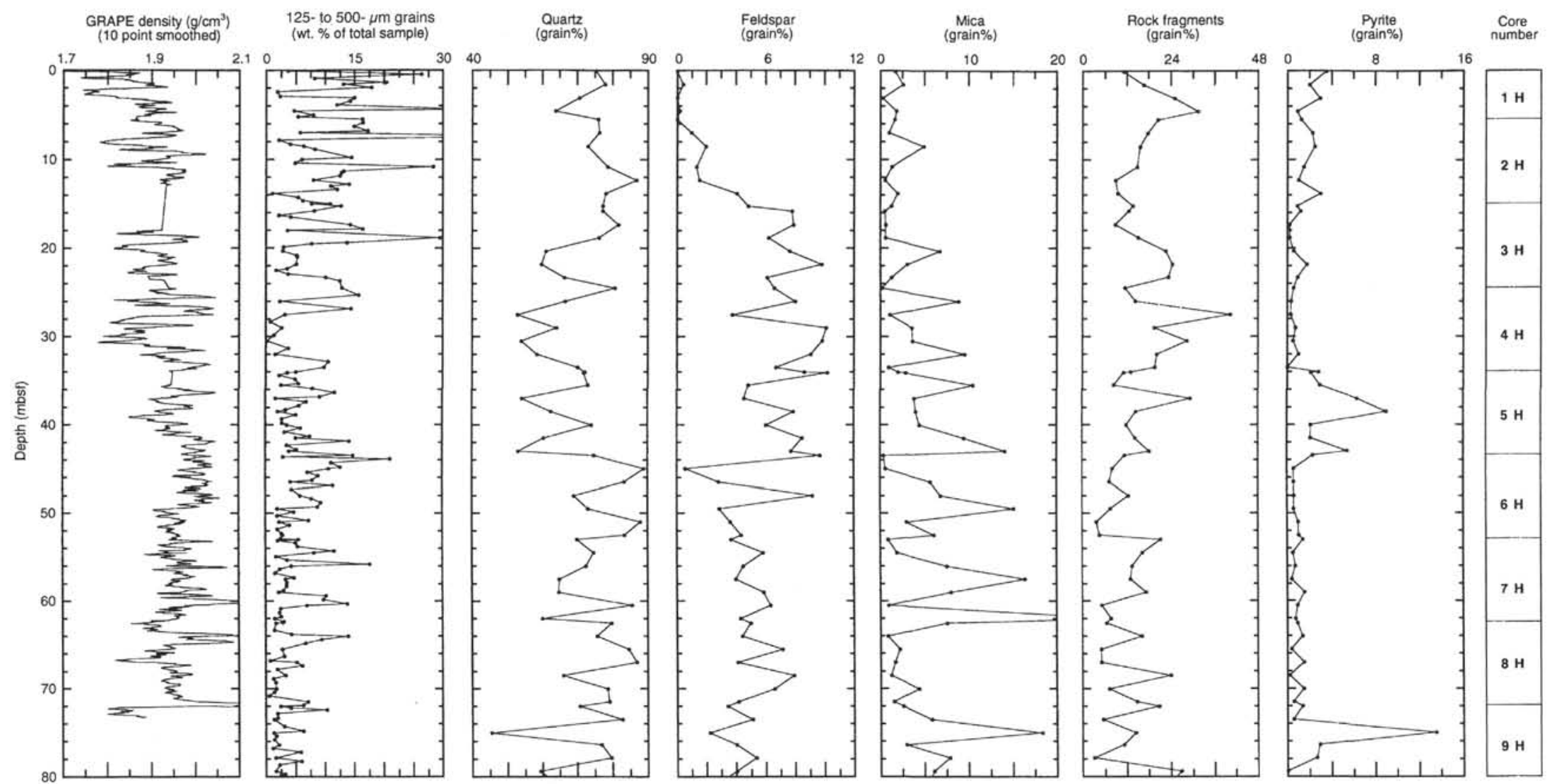

Figure 19. Comparisons between GRAPE bulk density and the results of visual compositional analyses (grain counts) of the 125- to 500- $\mu \mathrm{m}$ grain-size subfraction of the $>63-\mu \mathrm{m}$ fraction of discrete sediment samples from Hole 908A (data from Wolf-Welling et al., this volume). Compositional data are shown as grain percentages. 


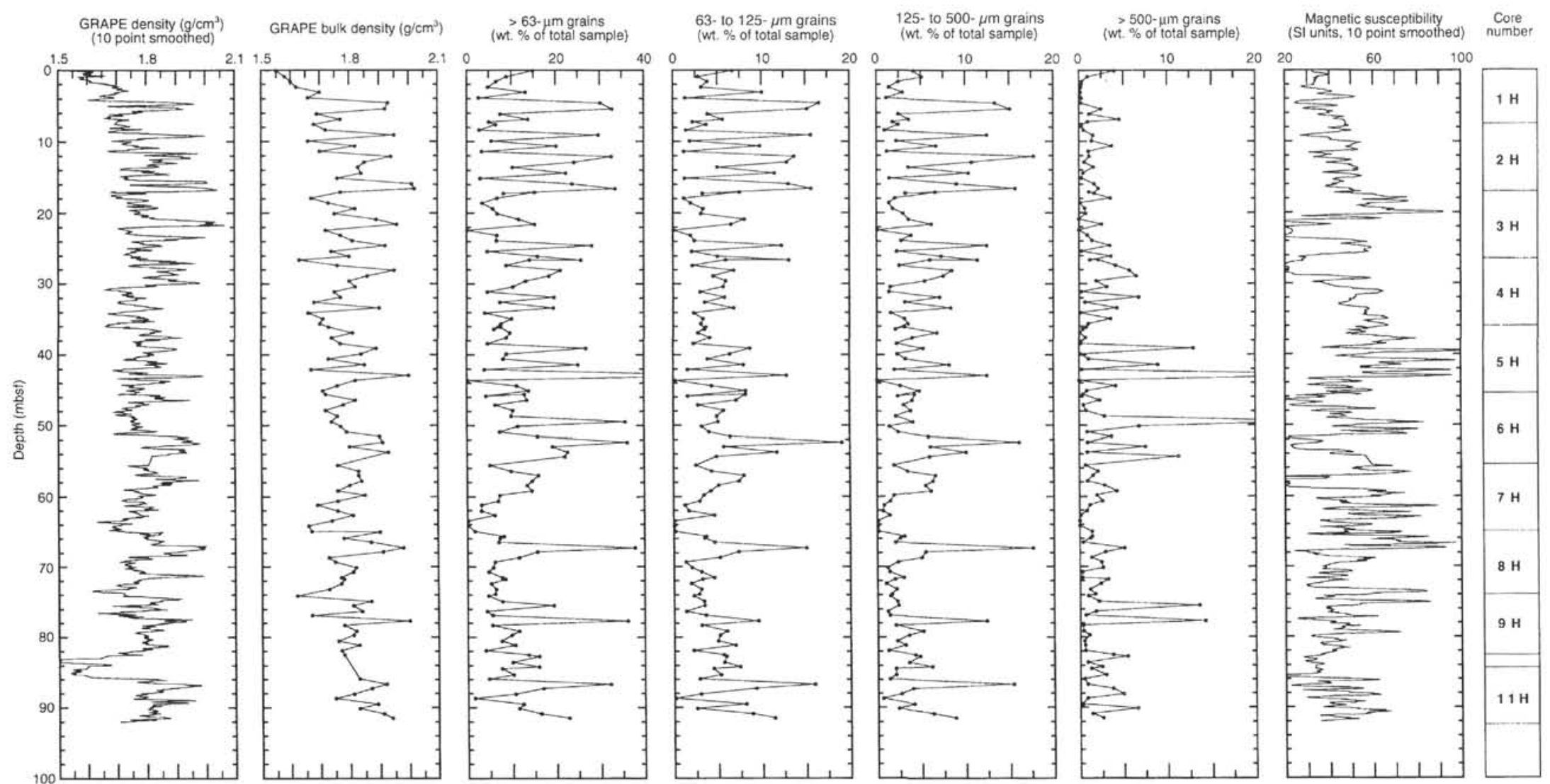

Figure 20. Comparisons between GRAPE bulk density and the results of textural analyses of discrete sediment samples from Hole 909A (data from Wolf-Welling et al., this volume). Note that GRAPE bulk density values shown in the second plot from the left correspond to the sediment samples used for textural analyses. 

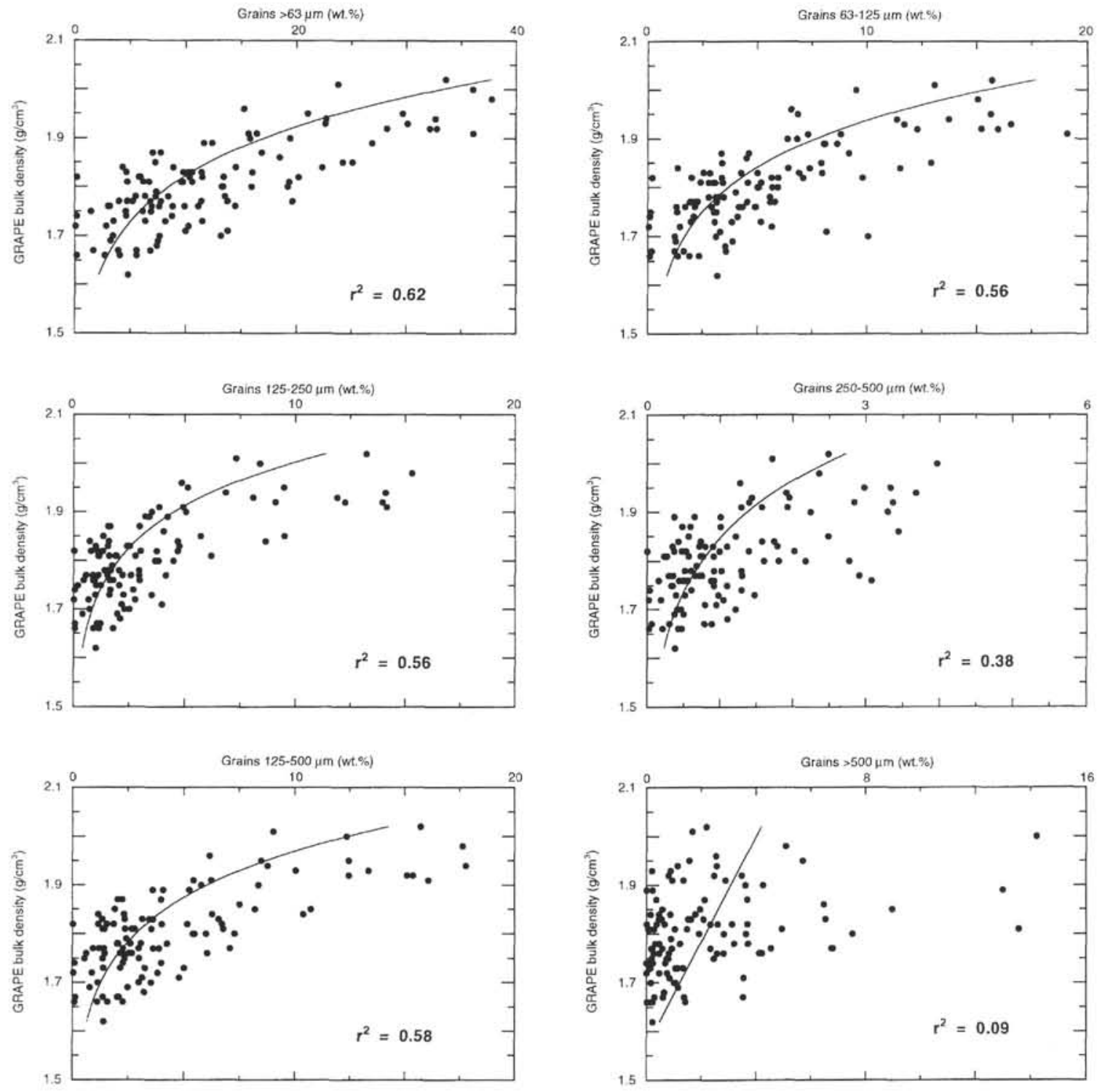

Figure 21. Interrelationships between GRAPE bulk density and textural data, Hole 909A. 


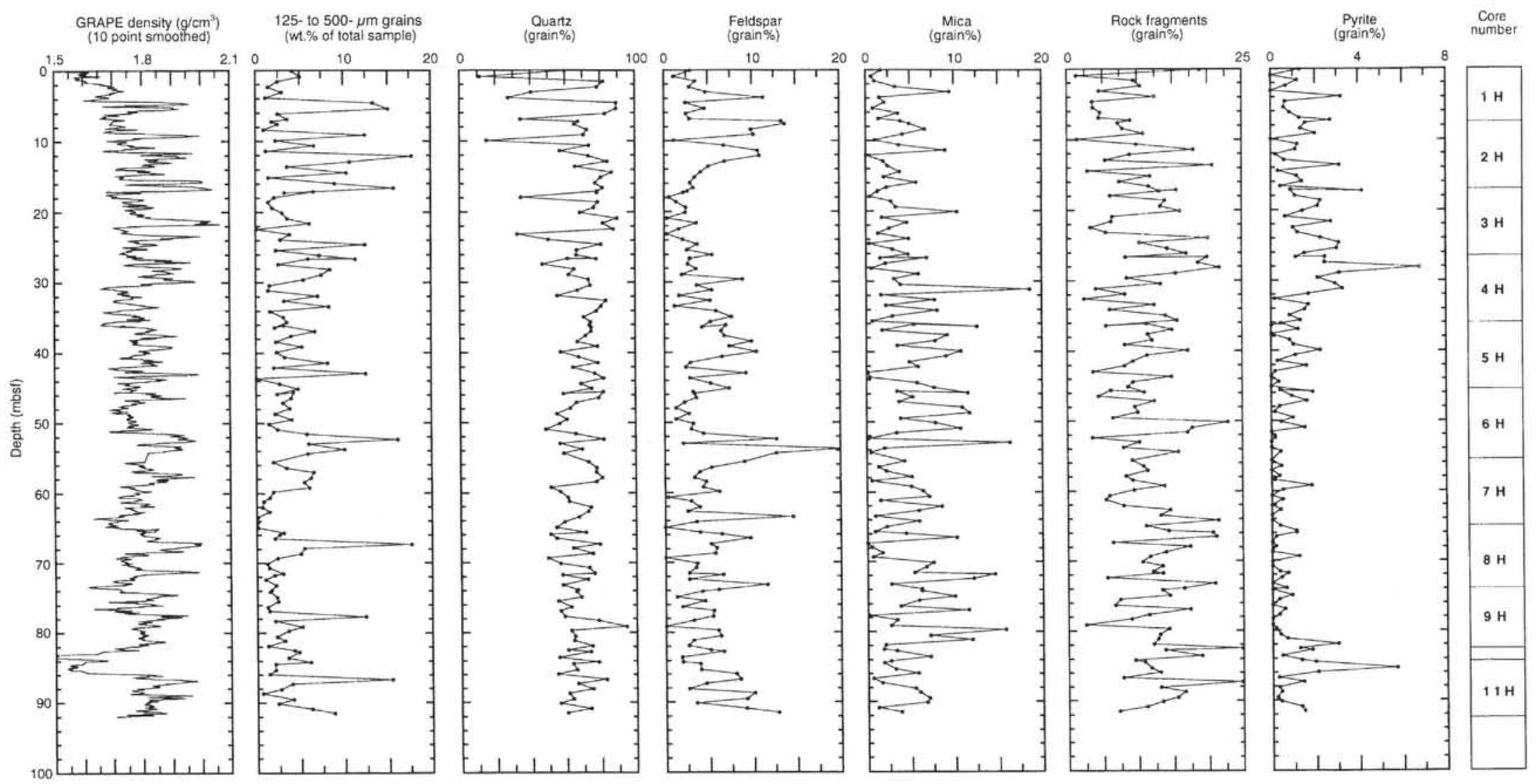

Figure 22. Comparisons between GRAPE bulk density and the results of visual compositional analyses (grain counts) of the $125-$ to $500-\mu \mathrm{m}$ grain-size subfraction of the $>63-\mu \mathrm{m}$ fraction of discrete sediment samples from Hole 909A (data from Wolf-Welling et al., this volume). Compositional data are shown as grain percentages. 


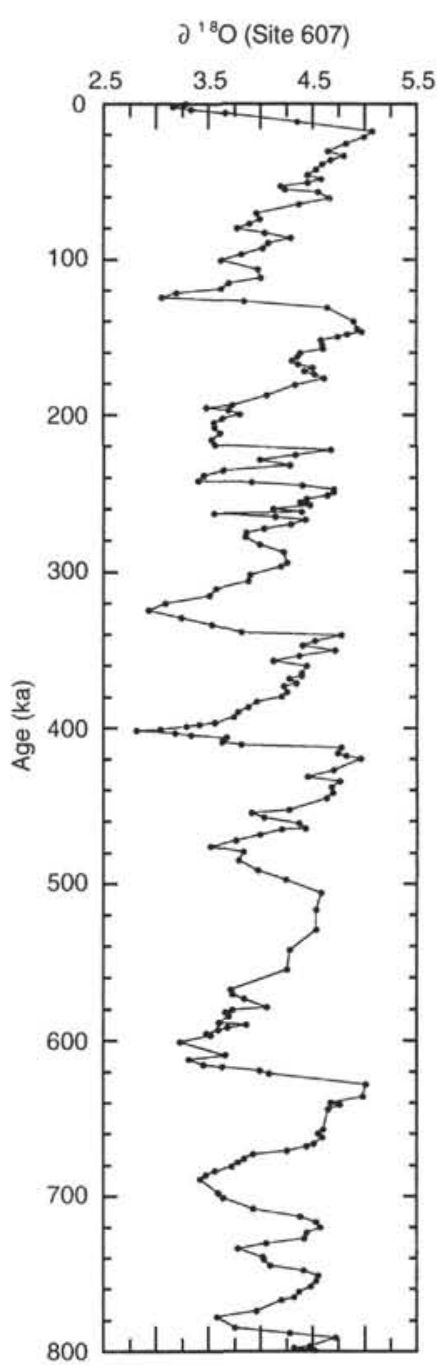

$$
\begin{gathered}
\text { GRAPE bulk density }\left(\mathrm{g} / \mathrm{cm}^{3}\right) \\
\text { (10 point smoothed) }
\end{gathered}
$$

Composite depth (m)

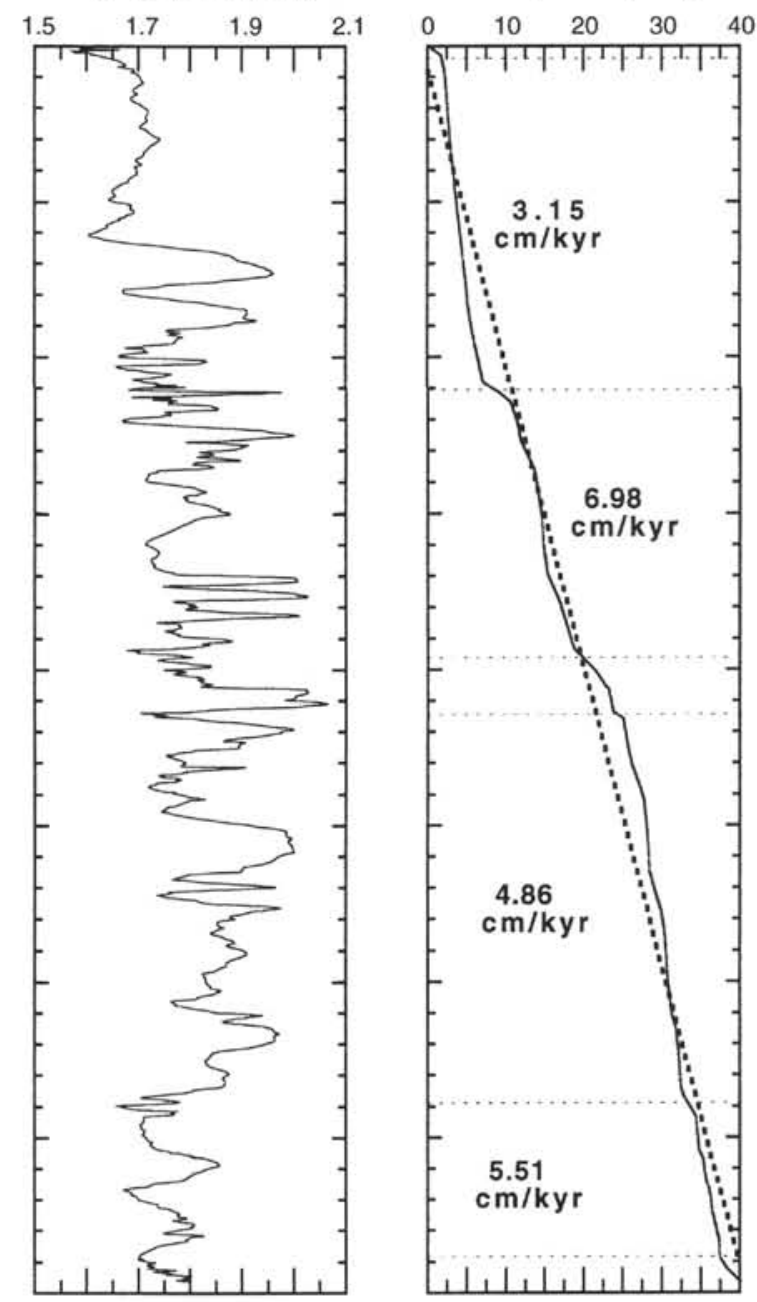

Figure 23. Graphical correlation between oxygen-isotope measurements plotted using the tuned age model from DSDP Site 607 (Ruddiman et al., 1989) and the (10 point smoothed) composite GRAPE bulk density record from Site 909 in Fram Strait. Increases in GRAPE bulk density values are assumed to correlate with heavier oxygen-isotope values (i.e., glacial maxima) in the Site 607 record. The linear sedimentation rate for selected intervals, derived from correlations with the Site 607 age model, are shown to the right. The overall linear sedimentation rate is $4.95 \mathrm{~cm} / \mathrm{ka}$. 
A GRAPE density $\left(\mathrm{g} / \mathrm{cm}^{2}\right)$

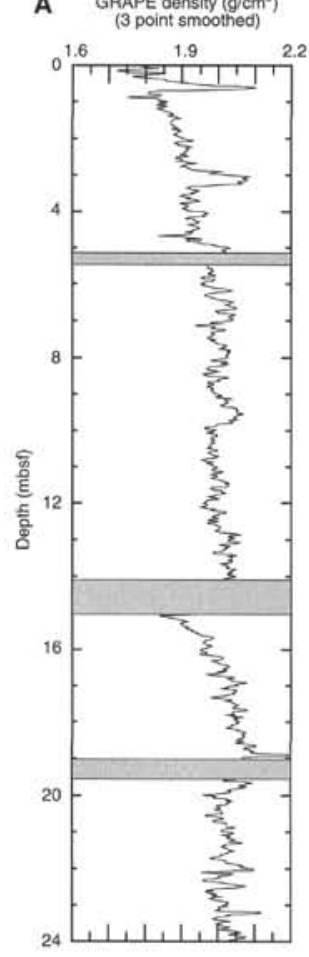

Peak Strength (kPa)$$
150
$$

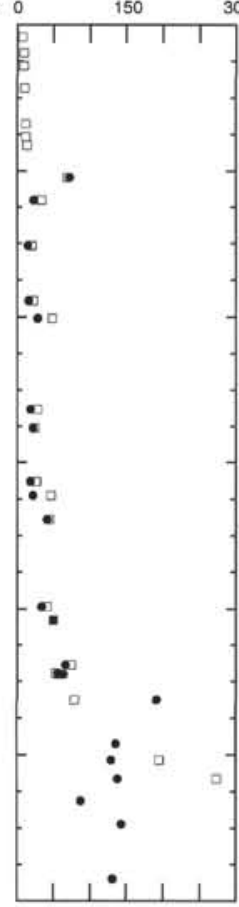

Magnetic susceptibility

(SI units) $\begin{array}{lllllll}10 & 20 & 30 & 40 & 50 & 60\end{array}$

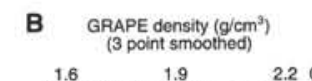

Number of Particles ( $>2 \mathrm{~mm} / 10 \mathrm{~cm}$ interval)

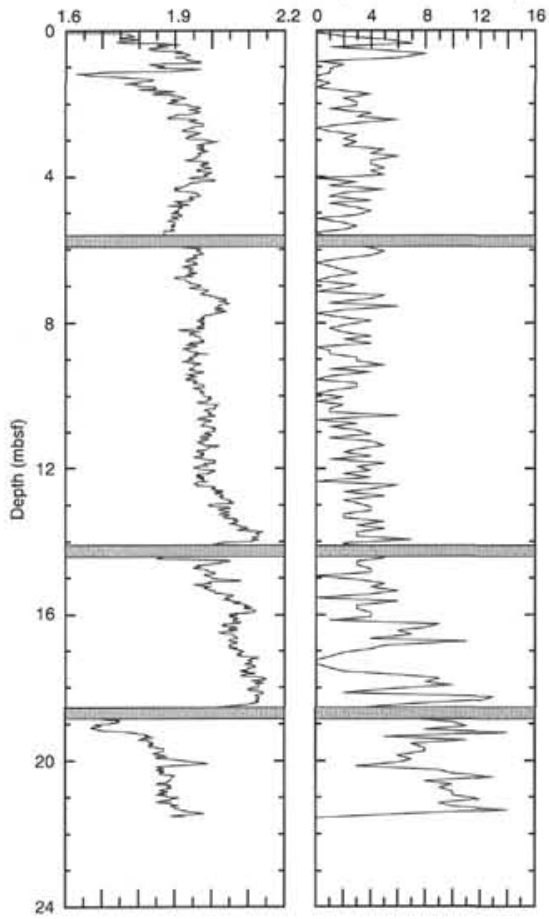

Magnetic susceptibility
(SI units) $\begin{array}{llllll}10 & 20 & 30 & 40 & 50 & 60\end{array}$
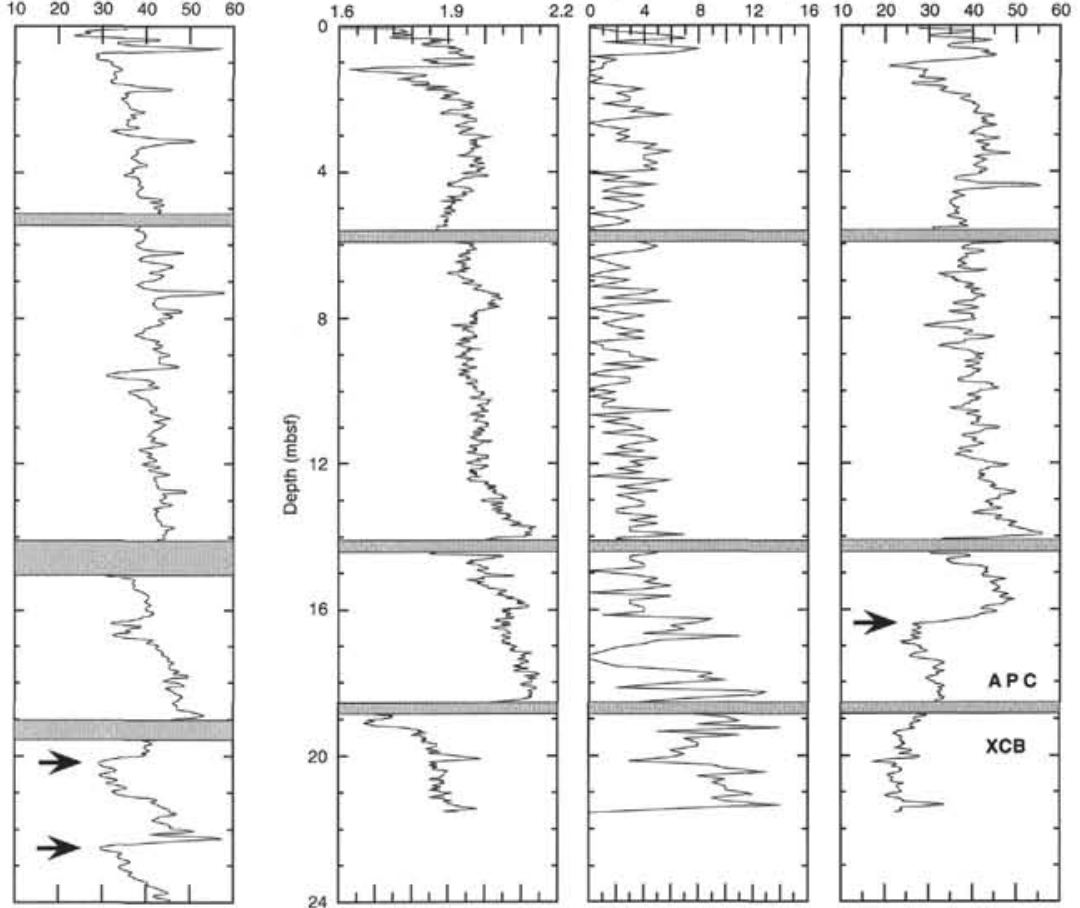

Figure 24. Comparison of downhole GRAPE bulk density and magnetic susceptibility profiles between Holes 910A (A) and 910D (B). Also shown are strength data from Hole 910A (open symbols = vane; solid symbols = penetrometer; see Myhre, Thiede, Firth, et al., 1995), and the number of particles ( $>2 \mathrm{~mm}$ in diameter/10-cm-interval of core) derived from an analysis of X-ray images taken of Hole 910D cores (Rack et al., this volume). Arrows mark the horizons where magnetic susceptibility records in either hole might be correlated. 


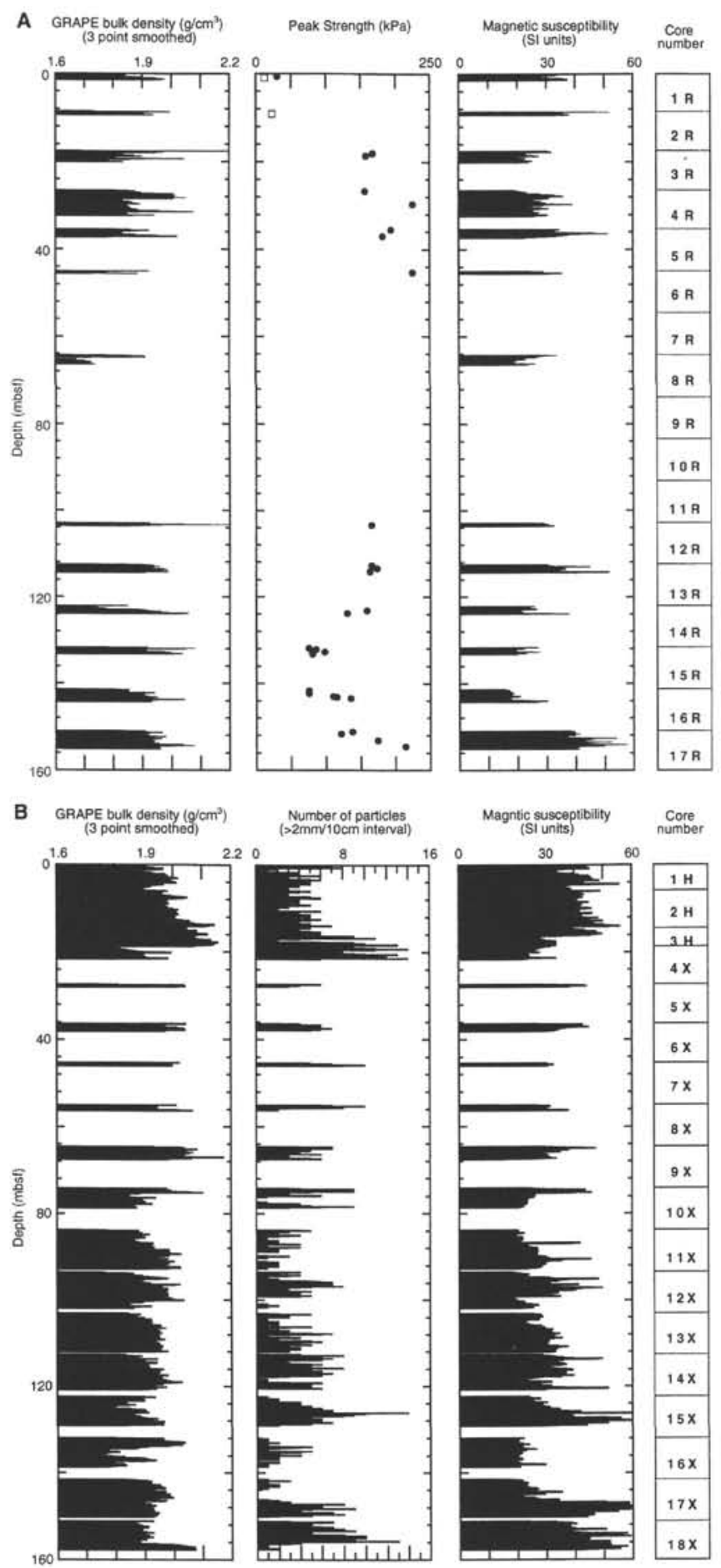

Figure 25. Comparison of downhole GRAPE bulk density and magnetic susceptibility profiles between Holes 910C (A) and 910D (B). Also shown are strength data from Hole 910A (open symbols = vane; solid symbols = penetrometer; see Myhre, Thiede, Firth, et al., 1995), and the number of particles ( $>2 \mathrm{~mm}$ in diameter/10-cm-interval of core) derived from an analysis of X-ray images taken of Hole 910D cores (Rack et al., this volume). 
F.R. RACK ET AL.
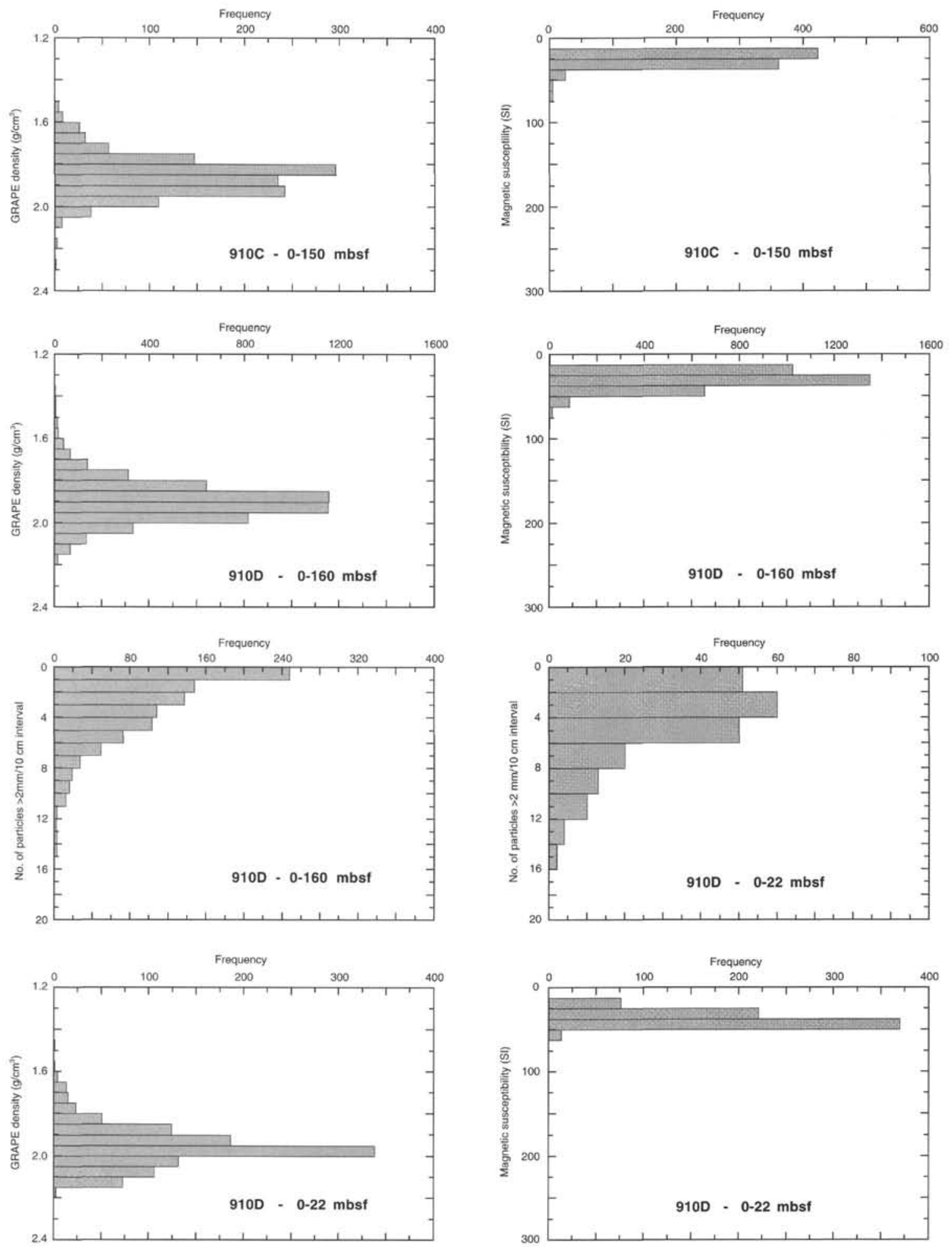

Figure 26. Comparisons between frequency distributions of GRAPE density and magnetic susceptibility data from Holes 910C and 910D, and the numbers of $X$-ray-interpreted clasts ( $>2 \mathrm{~mm}$ in diameter/10-cm-interval of core) from Hole 910D. The data from Hole 910D are grouped into two intervals to evaluate differences between the upper sequence ( $0-22 \mathrm{mbsf})$ and the entire cored interval ( $0-160 \mathrm{mbsf})$. 